\title{
A FUNÇÃO PUNITIVO-PREVENTIVA DA RESPONSABILIDADE CIVIL
}

THE PUNITIVE-PREVENTIVE ROLE OF TORTS

André Menezes Del Mastro*

\begin{abstract}
Resumo:
$\mathrm{O}$ artigo trata da evolução da responsabilidade civil e, principalmente, do desenvolvimento de sua função preventiva no século XXI. Outrossim, a pesquisa explica a discussão sobre a função punitiva da responsabilidade civil.

Palavras-chave: Responsabilidade Civil. Função punitiva. Função preventiva. Críticas. Dano moral.
\end{abstract}

\begin{abstract}
:
This paper aims to analyze the evolution of torts and mainly the development of its preventive role in 21 st century. Furthermore, this paper presents a debate about the punitive role of torts.
\end{abstract}

Keywords: Torts. Punitive damages. Preventive role. Criticisms. Moral damages.

1. A análise da responsabilidade civil

1.1. A construção moderna da responsabilidade civil

Tradicionalmente, a responsabilidade civil sempre visou ao retorno do statu quo ante em relação à ocorrência do dano. Após a consumação de um prejuízo a uma pessoa, a indenização buscada pelo instituto foi arquitetada com a finalidade de que a esfera jurídica do ofendido fosse a mesma daquela anterior ao dano.

A responsabilidade civil do indivíduo apenas nasce após a verificação de determinados pressupostos. Estes critérios são verdadeiros "filtros", ${ }^{1}$ de modo que não será qualquer situação que provocará a incidência do instituto.

Existem um dever originário e um dever sucessivo que marcam o instituto. ${ }^{2}$ Se uma pessoa tem a obrigação jurídica e não a cumpre, deve responder pelos eventuais danos decorridos de seu inadimplemento a partir da resolução do contrato. Assim, daquele dever originário descumprido nasce o dever sucessivo de indenizar o credor daquela obrigação. Tal é a responsabilidade civil contratual.

\footnotetext{
Graduando da Faculdade de Direito da Universidade de São Paulo. Este artigo é resultante do primeiro capítulo do trabalho de iniciação Científica com bolsa RUSP, sob a orientação do Prof. Dr. Marco Fábio Morsello, no período de 2012/2013 e apresentado no SIICUSP 2013.

1 SCHREIBER, Anderson. Novos paradigmas da responsabilidade civil: da erosão dos filtros da reparação à diluição dos danos. 4. ed. São Paulo: Atlas, 2012. p. 4.

2 CAVAlIERI FILHO, Sérgio. Programa de responsabilidade civil. São Paulo: Atlas, 2012. p. 2.
} 
Por outro lado, a responsabilidade civil extracontratual (ou aquiliana) caracteriza-se pelo dever originário de não lesar a outrem. Esta dualidade surgiu no contexto do século XIX com a expansão do capitalismo e com a importância dos contratos, de modo que estes eram vistos e tratados de maneira diversa dos negócios jurídicos unilaterais.

No século XVIII, três paradigmas norteavam a responsabilidade civil: ${ }^{3}$ culpa, individualização da responsabilidade e o paradigma da reparação integral, pelo qual os danos sofridos pela vítima deveriam ser ressarcidos in totum.

Primeiramente, o paradigma da culpa envolve a culpa lato sensu, abrangendo a culpa stricto sensu e o dolo. Ela possui uma concepção clássica e uma moderna. A visão clássica descreve a culpa como inerente à atitude que causa um dano previsível para o ofensor, ${ }^{4}$ ou seja, que poderia ter sido evitado se o indivíduo não agisse de maneira negligente, imprudente ou imperita. Vale ressaltar que a visão clássica da culpa demonstra o senso ético e moral que predominava em seu entendimento, atrelado à má utilização da liberdade individual causando o dano. ${ }^{5}$

Como se vê, no paradigma da culpa, a preocupação era eminentemente com a conduta do indivíduo, existindo uma censura sobre o exercício de sua liberdade individual causando danos a outrem.

$\mathrm{O}$ advento do século XX provocou a mudança do entendimento acerca da culpa, de modo que a concepção tornou-se objetiva ou normativa. ${ }^{6} \mathrm{~A}$ conduta do indivíduo seria analisada mediante standards relacionados aos princípios da boa-fé e da diligência. Analisa-se, no caso concreto, a intensidade da distorção entre o comportamento efetuado e aquele esperado. ${ }^{7}$ Neste sentido, Schreiber aduz que a aplicação da culpa normativa ou objetiva pode variar dependendo da proveniência ou da cultura do juiz. Ademais, aponta que certas atividades demandariam uma especialização do aplicador do direito, ou seja, cada setor ou tipo de conduta efetuada necessitaria de um vasto conhecimento sobre seu contexto. ${ }^{8}$

3 SERPA, Pedro Ricardo e. Indenização punitiva. 2011. Dissertação (Mestrado) - Faculdade de Direito, Universidade de São Paulo, São Paulo. p. 139 e ss.

4 SANTOS BRIZ, Jaime. La responsabilidade civil: derecho substantivo e derecho procesal. 3. ed. Madrid: Editora Montecorvo, 1981.p. 41 e ss.

5 SCHREIBER, Anderson. Novas tendências da responsabilidade civil brasileira. Revista Trimestral de Direito Civil, Rio de Janeiro, v. 22, p. 45-69, abr./jun., 2005. p. 48.

Novos paradigmas da responsabilidade civil: da erosão dos filtros da reparação à diluição dos danos. 4. ed. São Paulo: Atlas, 2012. p. 34-38 e Novas tendências da responsabilidade civil brasileira. Revista Trimestral de Direito Civil, Rio de Janeiro, v. 22, p. 45-69, abr./jun., 2005. p. 48.

7 MORAES, Maria Celina Bodin de. Danos à pessoa humana: uma leitura civil-constitucional dos danos morais. Rio de Janeiro: Renovar, 2003. p. 211 e SCHBEIRER, Anderson. Arbitramento do dano moral no Novo Código Civil. Revista Trimestral de Direito Civil, Rio de Janeiro, v. 12, out./dez. 2002. p. 5.

8 SCHREIBER, Anderson. Novos paradigmas da responsabilidade civil: da erosão dos filtros da reparação à 
O fenômeno da Revolução Industrial resultou no surgimento de danos os quais impunham uma dificuldade para as vítimas para comprovar a culpa do gestor do empreendimento. Se a vítima sofria um dano e pleiteava a indenização, havia o ônus de provar que o réu, seu patrão, havia culpa pelos danos, devido à responsabilidade eminentemente subjetiva da época.

Tendo em vista esses empecilhos para a prova da culpa por parte da vítima, muitas vezes, porque ela era um trabalhador que estava em um estado de inferioridade e de intimidação perante seu empregador e também porque estava em lugar distante de sua residência - o que o prejudicava no momento de pleitear a indenização. ${ }^{9}$

Com o escopo de reduzir essa dificuldade de prova a culpa do responsável pelo dano e diante das concepções oitocentistas tradicionais, a jurisprudência delimitou presunções de culpa que laboravam em favor das vítimas. ${ }^{10} \mathrm{O}$ passo seguinte dessa evolução foi a construção da responsabilidade objetiva, que não cogita de culpa, mas simplesmente do liame causal entre o dano e a atividade praticada. ${ }^{11}$

Observou-se que havia atividades que traziam um risco de danos intrínseco à natureza da atividade desempenhada. Por consequência, o dano era uma possibilidade iminente. Baseando-se no risco de danos que a atividade carrega, surgiu a teoria do risco, com várias modalidades.

Desse modo, a responsabilidade subjetiva tradicional e a responsabilidade objetiva passaram a coexistir, porém, isso não afastou os embates entre os defensores de cada uma. Os teóricos da responsabilidade subjetiva sustentavam que a responsabilidade objetiva causava um afastamento da preocupação com a pessoa, inerente à responsabilidade civil. Ademais, pugnavam que a aplicação desta vertente objetiva, haveria uma inércia do homem no que tange à realização das atividades econômicas. Outrossim, aduziam que o surgimento da responsabilidade objetiva iria de encontro à evolução da responsabilidade civil e caracteriza-se por um retorno ao tempo dos bárbaros.

Em resposta, os defensores da responsabilidade objetiva sustentavam, dentre outros aspectos, (i) que a teoria objetiva estava de acordo com os preceitos da

diluição dos danos. 4. ed. São Paulo: Atlas, 2012. p. 40 e ss.

9 CAVALIERI FILHO, Sérgio. Programa de responsabilidade civil. São Paulo: Atlas, 2012, p. 151 e AGUIAR DIAS, José de. Da responsabilidade civil. v. I. Rio de Janeiro: Forense, 1944, p. 65.

10 NORONHA, Fernando. Direito das Obrigações. 3. ed. São Paulo: Saraiva, 2010. p. 561. Neste sentido, ver SANTOS BRIZ, Jaime. La responsabilidad civil: derecho substantivo e derecho procesal. 3. ed. Madrid: Editora Montecorvo, 1981. p. 10 e AGUIAR DIAS, José de. Da responsabilidade civil. Rio de Janeiro: Forense, 1944. v. 1, p. 47-48 e p. 67 e ss. Aguiar Dias explica o fato de as presunções de culpa não terem conseguido facilitar por completo a prova da culpa e a responsabilidade do causador do dano.

11 A ideia de risco envolve a possibilidade de ele ocorrer, de modo que não se trata de um prejuízo certo. Assim, "o risco não é o dano ou prejuízo, mas a sua possibilidade" (LOPEZ, Teresa Ancona. Princípio da precaução e evolução da responsabilidade civil. São Paulo: Quartier Latin, 2010. p. 27-28). 
equidade e moral, na tendência da evolução da sociedade; (ii) parte de uma noção de solidariedade entre as pessoas; ${ }^{12}$ (iii) argumentavam que não haveria uma inércia da iniciativa das pessoas e que, na própria responsabilidade subjetiva, existia a ideia do risco nas presunções absolutas, nas quais não se possibilitava prova em contrário; (iv) a culpa não teria um contorno definido e que não havia um princípio jurídico que seja aplicável para todos os casos; (v) inexistia uma relação de teoria do risco com a vingança dos bárbaros porque esta não apresentava nenhum princípio moral em sua base. ${ }^{13}$

A responsabilidade objetiva encontra-se prevista no art. 927, parágrafo único, do CC. Sobre este dispositivo, a V Jornada de Direito Civil posicionou-se no enunciado n. 448:

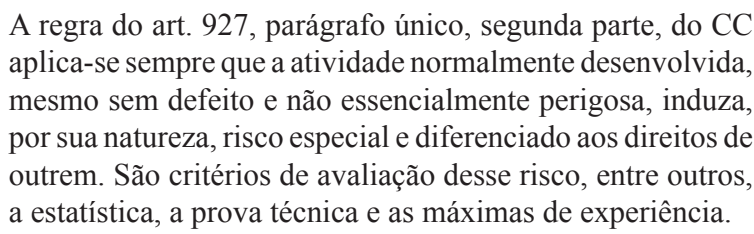

Nela, vemos a violação do dever de segurança, ou seja, se a atividade possui um risco inerente de dano, aquele que a exerce deve procurar adotar medidas de segurança para evitar danos. Dessa forma, ele não é responsável porque atua mediante uma atividade de risco, mas porque descumpriu o dever de segurança. ${ }^{14}$

Uma atividade lícita carrega em si um perigo abstrato ou um risco de dano, de maneira que eventual dano será antijurídico e proporcionará o direito de ser indenizado. O juízo que se faz na responsabilidade objetiva é posterior ao dano. No caso da responsabilidade subjetiva, é possível exercer um juízo de censura da conduta do indivíduo previamente ao dano. ${ }^{15}$ A conduta pode ser antijurídica, porém se não houver dano não se pode dizer que o indivíduo será responsabilizado.

Em contrapartida, a responsabilidade objetiva não permite uma censura em momento anterior ao dano porque a atividade é lícita. Ela provoca um perigo (abstrato) de dano futuro que, ao concretizar-se, ensejará a responsabilidade. A partir do dano superveniente, antijurídico, nasce a responsabilidade objetiva. Ante o exposto, vê-se que

\footnotetext{
12 LOPEZ, Teresa Ancona. Princípio da precaução e evolução da responsabilidade civil. São Paulo: Quartier Latin, 2010. p. 49.

13 AGUIAR DIAS, José de. op. cit., p. 72-84. A teoria do risco recebeu sérias críticas dos defensores da doutrina subjetiva, sob o argumento de que, em razão da demasiada atenção à vítima, acaba por negar o princípio da justiça social, impondo cegamente o dever de reparar, e levando-o a equiparar o comportamento jurídico e o injurídico do agente (CAVALIERI FILHO, Sérgio. Programa de responsabilidade civil. São Paulo: Atlas, 2012. p. 155).

14 CAVALIERI FILHO, Sérgio. op. cit., p. 155.

15 ZANNONI, Eduardo. El daño en la responsabilidad civil. 2. ed. Buenos Aires: Astrea, 1993. p. 6-7.
} 
esta adota o conceito de antijuridicidade do dano, de modo que a obrigação de indenizar apenas surge com o dano. ${ }^{16}$

A respeito da teoria do risco, diversas modalidades foram delineadas, dependendo da atividade exercida: risco integral, risco profissional, risco proveito e risco criado. ${ }^{17} \mathrm{O}$ risco integral envolve situações nas quais o dano advém de atividades de natureza perigosa, como as nucleares, não havendo possibilidade de se eximir de responsabilidade provando a ausência de nexo de causalidade nem de prova de realização de medida de segurança ou de cuidado. A teoria do risco profissional abrange atividades laborais nas quais o trabalhador está diante de risco de sofrer danos, como lesões corporais em máquinas, comuns no período da Revolução Industrial. O risco proveito compreende situações em que o indivíduo desenvolve uma atividade que gera um risco de danos à sociedade, enquanto que ele aufere lucros. Assim, este enriquecimento atrelado à construção do risco é o fundamento da responsabilidade objetiva neste caso. A teoria do risco criado, por sua vez, busca abranger qualquer espécie de atividade realizada por um indivíduo que promova um risco para terceiros, ainda que de pequena intensidade.

Noronha ${ }^{18}$ sustenta que a responsabilidade civil passou por três mudanças em sua evolução. A primeira consiste na expansão dos danos ressarcíveis, que se consumou, por exemplo, na reparação dos danos, decorrente de uma valorização do indivíduo, e na existência de uma maior tutela jurídica da pessoa. ${ }^{19}$ A segunda mudança é o surgimento da responsabilidade objetiva. A terceira mudança foi o desenvolvimento da coletivização ${ }^{20}$ da responsabilidade, que deixa de ser apenas individual. Os danos passam a ser ressarcidos pela sociedade e o mecanismo para essa coletivização é o seguro. ${ }^{21}$

Em uma perspectiva voltada para a função da responsabilidade civil, Lopez realizou um estudo a respeito da evolução da responsabilidade civil. Uma de suas

16 ZANNONI, Eduardo. El daño en la responsabilidad civil. 2. ed. Buenos Aires: Astrea, 1993. p. 4-5.

17 CAVALIERI FILHO, Sérgio. op. cit., p. 152 e ss.

18 NORONHA, Fernando. Direito das obrigações. 3. ed. São Paulo: Saraiva, 2010. p. 564.

19 Marinangelo também chama a atenção para essa mudança do direito que está muito associada com a própria evolução da sociedade e com os valores presentes com os novos tempos (MARINANGELO, Rafael. A evolução da indenização por dano moral e a aplicação da indenização punitiva, In: LOTUFO, Renan; NANNI, Giovanni Ettore; MARTINS, Fernando Rodrigues (Org.). Temas relevantes do direito civil contemporâneo: reflexões sobre os 10 anos do Código Civil. São Paulo: Atlas, 2012. p. 670).

20 Num processo que ocorreu principalmente após a Segunda Guerra Mundial, a responsabilidade civil passou a abordar e abranger a solidariedade social. Não se cogita em saber qual o agente do dano ou se ele responde objetivamente, bem como as causas para o dano, mas, principalmente se pensa na indenização das vítimas. A busca da indenização integral dos danos torna-se o foco da responsabilidade civil com base no princípio da solidariedade (LOPEZ, Teresa Ancona. Princípio da precaução e evolução da responsabilidade civil. São Paulo: Quartier Latin, 2010. p. 60.

21 NORONHA, Fernando. op. cit., p. 568. Ver também SCHREIBER, Anderson. Novas tendências da responsabilidade civil brasileira. Revista Trimestral de Direito Civil, Rio de Janeiro, v. 22, p. 45-69, abr./ jun., 2005. p. 67-69 e Novos paradigmas da responsabilidade civil: da erosão dos filtros da reparação à diluição dos danos. 4. ed. São Paulo: Atlas, 2012. p. 225 e ss. 
conclusões é de que a responsabilidade civil do século XXI exerce a função preventiva de danos, de modo que a mera reparação não é mais a principal finalidade.

Sua evolução demonstra a preocupação com a pessoa humana e com a reparação dos danos e esta foi se substanciando em ferramentas para propiciar uma maior proteção da sociedade. Neste sentido, vê-se o surgimento da responsabilidade objetiva, a socialização dos riscos e, agora, o fortalecimento dos princípios da prevenção e da precaução na responsabilidade civil. ${ }^{22}$

Conforme vimos, houve uma facilitação no procedimento de responsabilização do ofensor, mediante a responsabilidade objetiva na qual é despicienda a comprovação da culpa. Ademais, logrou-se em proteger uma quantidade maior de danos, como o dano moral, exprimindo uma tutela da sociedade e depois uma coletivização dos danos com o objetivo de propiciar indenizações para as vítimas. Por fim, vê-se, atualmente, o fortalecimento da preocupação em evitar danos e antecipar-se a eles, não somente indenizá-los posteriormente. Trata-se da função preventiva. ${ }^{23}$

\subsection{Função preventiva}

Diante da realidade marcada por riscos e incertezas a respeito da ocorrência de novos danos, sejam ou não conhecidos, a função principal da responsabilidade civil atualmente é a preventiva.

Tal escopo preventivo foi objeto de enunciado na V Jornada de Direito Civil, de novembro de 2011. Assim, consta no enunciado n. 446: “Art. 927. A responsabilidade civil prevista na segunda parte do parágrafo único do art. 927 do Código Civil deve levar em consideração não apenas a proteção da vítima e a atividade do ofensor, mas também a prevenção e o interesse da sociedade".

Nota-se facilmente a intensificação dos riscos. ${ }^{24} \mathrm{Na}$ medicina, temos os efeitos colaterais dos remédios e os riscos inerentes a qualquer prática médica. Além

22 LEVY, Daniel de Andrade. Responsabilidade civil: de um direito dos danos a um direito das condutas lesivas. São Paulo: Atlas, 2012. p. 27 e ss. O autor ressalta a importância da reparação dos danos, mas indica novas funções da responsabilidade civil atual. Ela assumiria a função preventiva e a função punitiva, sendo esta um instrumento de prevenção. Ao lado da conduta e do nexo de causalidade que seriam construções jurídicas, o autor explica que o dano demonstra o contato existente entre a sociedade e o Direito, porque aquele manifesta os interesses que a sociedade pretende tutelar juridicamente.

23 "A vítima do dano, e não mais o autor do ato ilícito, passa a ser o enfoque central da responsabilidade civil. Em outras palavras, a responsabilidade, antes centrada no sujeito responsável, volta-se para a vítima e a reparação do dano por ela sofrido" (CAVALIERI FILHO, Sérgio. Programa de responsabilidade civil. São Paulo: Atlas, 2012. p. 166).

24 Lopez realiza uma distinção entre perigo, álea e risco. O perigo é aquela situação real e concreta em que o dano pode ocorrer. Trata-se da real possibilidade de um dano vir a acontecer. Diferentemente, a álea é aquele acontecimento que é inevitável e que traz grandes prejuízos. Compreende acontecimentos que são excludentes da responsabilidade civil (art. 393, CC). Ademais, o risco caracteriza-se por ser um perigo um 
disso, vê-se, por exemplo, riscos nos transportes, no terrorismo e em outras formas de violência, etc.

A sociedade contemporânea é caracterizada pela ubiquidade do medo e dos riscos e isso se reflete na responsabilidade civil. O "medo secundário" 25 está muito presente, consubstanciado no receio das pessoas de que danos ocorram contra elas.

$\mathrm{O}$ risco de que se fala na função preventiva é diversa daquele presente na responsabilidade objetiva. Nesta, o risco das atividades econômicas forçou o reconhecimento de responsabilidade mediante a prova do dano e do nexo de causalidade. Retirou-se a exigibilidade da prova da culpa para permitir uma responsabilização objetiva. Ao abordar a função preventiva, fala-se de risco de dano com a finalidade de se antecipar a eles, de gerenciar as possibilidades de algum prejuízo vir a ocorrer e de efetivar medidas que os evitem.

Levy explica que, hoje, "o risco tem necessariamente uma dimensão prognóstica, refletida na potencialidade de dano de um evento que ainda não ocorreu". ${ }^{26}$ Enquanto que a responsabilidade objetiva teve uma preocupação voltada para o dano que ocorre com a vítima, a ideia de risco, atualmente, procura se basear em um âmbito preventivo.

O escopo protetivo da responsabilidade civil intensifica-se. Na passagem da responsabilidade subjetiva para a responsabilidade objetiva, visou-se a uma facilitação da responsabilização e, por conseguinte, das indenizações às vítimas, tendo em vista as dificuldades enfrentadas pelas vítimas no paradigma da culpa. Agora, o foco não é simplesmente fornecer uma compensação do dano, mas permitir que a sociedade não sofra qualquer espécie de prejuízo atrelado a um dano. Nesta tarefa contemporânea da responsabilidade civil, os princípios da prevenção e da precaução serão aplicados.

Os princípios da prevenção e da precaução assumem o escopo da responsabilidade civil, de modo que se devem prevenir os danos já conhecidos (prevenção) e hipotéticos (precaução) e presentes em todas as atividades, com suas peculiaridades próprias.

No que concerne à origem da precaução, ela sempre existiu na sociedade, como uma maneira de se evitar danos na sociedade e seus perigos. Entretanto, a realidade

pouco previsível e também abstrato. Há os riscos hipotéticos, sobre os quais se levanta as possibilidades de eles acontecerem. Se elas forem grandes e consideráveis, os riscos tornam-se comprovados. Não há um risco nulo porque ele sempre pode acontecer, principalmente, se levarmos em conta a sociedade rica em inovação e em mudanças como a atual. (LOPEZ, Teresa Ancona. Princípio da precaução e evolução da responsabilidade civil. São Paulo: Quartier Latin, 2010. p. 24).

25 BAUMAN, Zygmunt. Medo líquido. Trad: Carlos Alberto Medeiros. Rio de Janeiro: Zahar, 2008. p. 9 e ss.

26 LEVY, Daniel de Andrade. Responsabilidade civil: de um direito dos danos a um direito das condutas lesivas. São Paulo: Atlas, 2012. p. 146. 
vivida coloca situações nas quais não se conhece propriamente as características destes possíveis danos, ou seja, nem sempre se conhece os efeitos lesivos.

O princípio da precaução tem origem no direito ambiental, mais precisamente no direito alemão, na década de 70. Ao longo dos anos, apareceu em discussões acerca de temas ambientais, como a "Conferência das Nações Unidas sobre Meio Ambiente Humano", que ocorreu em Estocolmo em 1972. Posteriormente, o princípio da precaução foi tratado na "Conferência sobre o Mar do Norte". ${ }^{27}$

O intuito de precaução se consagrou como princípio na Declaração do Rio de Janeiro, na Eco-92. No art.15 da Declaração, vê-se a aplicação do princípio da precaução em riscos de danos ainda que eles sejam hipotéticos e desconhecidos pela ciência.

De modo a proteger o meio ambiente, o princípio da precaução deve ser amplamente observado pelos Estados, de acordo com suas capacidades. Quando houver ameaça de danos sérios e irreversíveis, a ausência de absoluta certeza científica não deve ser utilizada como razão para postergar medidas eficazes e economicamente viáveis para prevenir a degradação ambiental.

O princípio da precaução estendeu-se para outras áreas do Direito, como o direito sanitário, direito do consumidor e direito médico. Lopez conceitua-o:

Princípio da precaução é aquele que trata das diretrizes e valores do sistema de antecipação de riscos hipotéticos coletivos ou individuais, que estão a ameaçar a sociedade ou seus membros com danos graves e irreversíveis e sobre os quais não há certeza científica; esse princípio exige a tomada de medidas drásticas e eficazes com o fito de antecipar o risco suposto e possível, mesmo diante da incerteza. ${ }^{28}$

Como o contexto era marcado pela responsabilidade objetiva, a questão que se suscitou era de se a teoria do risco e a responsabilidade objetiva seriam eficazes no estágio atual de desenvolvimento da humanidade, em que há "novos riscos" desde o final do século XX. Sobre o assunto, Lopez defende a insuficiência da teoria do risco, inclusive a vertente do risco integral, que a torna incapaz de solucionar os problemas atuais que ocorrem na responsabilidade civil. ${ }^{29}$

27 LOPEZ, Teresa Ancona. Princípio da precaução e evolução da responsabilidade civil. São Paulo: Quartier Latin, 2010. p. 96-97. No mesmo sentido, HARTMANN, Ivar Alberto Martins. O princípio da precaução e sua aplicação no direito do consumidor: dever de informação. Revista de Direito do Consumidor, a. 18, n. 70, p. 172-235, abr./jun., 2009. p. 173 e ss.

28 LOPEZ, Teresa Ancona. op. cit., p. 102.

29 Ibid., p. 49. 
$\mathrm{Na}$ responsabilidade objetiva, o escopo de se permitir uma indenização às vítimas provocou o descomprometimento do instituto com as condutas lesivas, ou seja, o intuito de indenizar tornou-se mais importante do que censurar as condutas e evitálas. Diferentemente, vê-se que a tutela preventiva atua sobre as condutas e práticas dos indivíduos, estando próxima a estas.

Outro fator importante relaciona-se aos seguros, no contexto da socialização dos riscos. ${ }^{30} \mathrm{O}$ escopo dos seguros era fornecer uma indenização às vítimas de maneira imediata, sendo que não se cogitava da culpa ou de perquirir a respeito do causador dos danos. Assim, o efeito deste mecanismo foi a criação de um sentimento de despreocupação com a causa dos danos para uma futura prevenção.

Semelhante ao seguro, a responsabilidade objetiva causou um descompromisso com a prevenção. As indenizações ocorriam após a prova do nexo de causalidade entre o dano e a atividade de risco. Os empreendedores e gestores das atividades buscavam compreender o preço das indenizações no próprio preço de seus produtos e serviços, mediante cálculo atuarial. ${ }^{31}$

A reparação dos danos não deve ser mais o norte da responsabilidade civil e de sua evolução. Diante do surgimento de novos riscos, cujos efeitos não sabemos com propriedade, principalmente com o aprimoramento das tecnologias, os princípios da prevenção e da precaução devem ser aplicados, preliminarmente a qualquer preocupação indenizatória.

O fundamento ético do princípio da precaução é a prudência e o fundamento jurídico está presente nos princípios da segurança, do princípio da solidariedade e no princípio da dignidade humana. ${ }^{32}$

30 Morsello realiza uma análise da socialização dos riscos na Nova Zelândia e nos países escandinavos e conclui com a existência de problemas decorrentes dela, como a desvalorização da moeda, problemas vinculados à limitação das indenizações e ausência de prevenção dos danos. "Depreende-se, portanto, que a socialização integral dos riscos gera problemas de escala competitiva na sociedade globalizada, de modo que, não obstante restem válidos os valores de solidariedade social e garantia de tutela da dignidade humana, não se poderá carrear somente ao Estado referido ônus, máxime tendo em vista que, mesmo no rol dos países do 'Primeiro Mundo', se nota que o ônus exclusivo do Estado e, por via de consequência, da sociedade, dá azo ao aumento de sinistros, na medida em que o indivíduo não vislumbra sérias consequências patrimoniais advindas de sua conduta, que onerarão o corpo social”. (MORSELLO, Marco Fábio. A responsabilidade civil e a socialização dos riscos. O sistema neozelandês e a experiência escandinava. Revista da Escola da Magistratura, a. 7, n. 2, jul./dez. 2006. p. 13 e ss.).

31 LOPES, José Reinaldo de Lima. Responsabilidade civil do fabricante e defesa do consumidor. São Paulo: Revista dos Tribunais, 1992. p. 94 apud SERPA, Pedro Ricardo e. Indenização punitiva. 2011. Dissertação (Mestrado) - Faculdade de Direito, Universidade de São Paulo, São Paulo. p. 157.

32 LOPEZ, Teresa Ancona. Princípio da precaução e evolução da responsabilidade civil. São Paulo: Quartier Latin, 2010.p. 110 e ss. No mesmo sentido, DONNINI, Rogério. Prevenção de danos e a extensão do princípio neminem laedere, In: NERY, Rosa Maria de Andrade; DONNINI, Rogério (Org.). Responsabilidade civil: estudos em homenagem ao Professor Rui Geraldo Camargo Viana. São Paulo: Revista dos Tribunais, 2009. p. 494-498. 
O princípio da solidariedade figura como um dos objetivos da República (art. $3^{\circ}$, I, da CF). Este princípio surge como orientação da interpretação das normas jurídicas e para garantir que os danos não fiquem impunes, compreendendo a responsabilidade civil. $^{33}$

O princípio da segurança é uma garantia aos cidadãos (art. $5^{\circ}$, caput, da $\mathrm{CF}$ ) e um direito social (art. $6^{\circ}$, da CF). No plano infraconstitucional, a obrigação de segurança está presente no art. $6^{\circ}$, do CDC e no art. $1^{\circ}$ da Lei de Biossegurança (Lei n. $11.105 / 2005) .{ }^{34}$ No próprio princípio n. 15 da Declaração da Eco-92 ${ }^{35}$ a segurança foi compreendida.

Tendo em vista que a aplicação do princípio da precaução é em um momento anterior ao dano, que é hipotético e abstrato, uma das críticas feitas contra o referido princípio é de que ele é um empecilho ou um obstáculo para o "progresso tecnológico e científico". ${ }^{36}$ Para que não obste o desenvolvimento científico, é preciso que o princípio seja aplicado com razoabilidade, no sentido de precaver danos e não para promover uma situação pior com entraves ao progresso.

Existe também a crítica de que o princípio da precaução é abstrato, de modo que não é possível determinar exatamente o que seria uma "ameaça de danos sérios e irreversíveis". Outrossim, critica-se o fato de que não se sabe o que é certeza científica. Uma atividade pode ser entendida como perigosa em uma determinada época, de sorte que o interessado deve comprovar a inexistência de periculosidade e, com o avanço da tecnologia e da ciência, a comunidade científica notar que aquela atividade não trazia muitos riscos de danos sérios à sociedade. Neste contexto, a Declaração da Eco-92 tratou de frisar que a certeza científica não é um elemento indispensável para a aplicação do princípio da precaução. ${ }^{37}$

Os princípios da prevenção e da precaução causam um interessante efeito na responsabilidade civil. A finalidade de se antecipar aos danos e evitá-los, mediante a

33 LOPEZ, Teresa Ancona. op. cit., 115.

34 HARTMANN, Ivar Alberto Martins. O princípio da precaução e sua aplicação no direito do consumidor: dever de informação. Revista de Direito do Consumidor, a. 18, n. 70, p. 172-235, abr./jun., 2009. p. 178.

35 Este mesmo princípio está presente na Convenção de Diversidade Biológica, promulgada pelo Decreto n. 2519/98 e na Convenção do Quadro das Nações Unidas sobre Mudança do Clima, com promulgação dada com o Decreto n. 2.652/98. Elas orientam o princípio da precaução na situação vinculada à fauna e às mudanças climáticas (LEWICKI, Bruno. Princípio da precaução: impressões sobre o segundo momento. In: MORAES, Maria Celina Bodin de (Coord.). Princípios do direito civil contemporâneo. São Paulo: Renovar, 2006. p. 365).

36 LOPEZ, Teresa Ancona. op. cit., p. 87. Lewicki chama a atenção para o perigo da utilização exagerada deste princípio podendo provocar sua inutilização. Ademais, defende que deixar de aplicar o princípio prejudica as próprias atividades econômicas (LEWICKI, Bruno. op. cit., p. 382-383). Hartmann ressalta que o princípio deve ser harmonizado com os interesses econômicos. A OMC já afirmou a importância do princípio em face de aspectos econômicos (HARTMANN, Ivar Alberto Martins. op. cit., p. 187-189).

37 HARTMANN, Ivar Alberto Martins. op. cit., p. 179-183. 
cautela, o cuidado nas atividades econômicas, a efetivação de pesquisas, dentre outras medidas, suscitam o retorno da importância do elemento culpa para a responsabilidade civil.

Sabemos que a culpa permaneceu nas atividades liberais, apesar da responsabilidade objetiva, ${ }^{38}$ porém, agora ela passa a estar presente em diversas atividades, exigindo que haja uma tomada de cautela maior, relacionando-se à aplicação dos princípios da prevenção e da precaução. ${ }^{39}$

Aquele indivíduo que não toma o devido cuidado é considerado responsável pelos danos que acontecerem mediante uma presunção iuris tantum, que só é afastada com a prova da cautela efetivada. ${ }^{40}$

Ante o exposto, vê-se que a função preventiva da responsabilidade civil, manifestada pelos princípios da prevenção e da precaução, coloca a indenização como algo secundário diante da finalidade de se evitar o dano. A preocupação antiga de propiciar indenizações às vítimas deve ser substituída, portanto, pelo intuito de tornar a sociedade com menor quantidade de dano.

A atuação dessa função dá-se em um momento prévio ao dano e posterior a ele. Assim, procura-se inserir medidas que possam anteceder ao dano. Ademais, existem medidas que procuram disciplinar o agente que comete danos para que este não volte a exercer sua atividade lesiva. Aqui não é somente o efeito de punir, mas de educar e de prevenir danos. Neste sentido, a função punitiva da responsabilidade civil é um caminho de atuação da função preventiva, podendo-se falar de função punitivo-preventiva. ${ }^{41}$

38 LOPEZ, Teresa Ancona. Princípio da precaução e evolução da responsabilidade civil. São Paulo: Quartier Latin, 2010. p. 144 e ss.

39 MARTIN, Gilles. Précaution et évolution du droit. In: GODARD, Oliver. Principe de précaution, p. 343344 apud LOPEZ, Teresa Ancona. op. cit., p. 144. A culpa passa por mudanças com a defesa da prevenção e da precaução. Ela passa a abranger também uma maior prudência em determinadas ocasiões, revitalizandose. "Portanto, é possível afirmar que a culpa na atualidade está adquirindo novos contornos, sob a influência do princípio da precaução e prevenção, atuando também como um mecanismo de prevenção de dano. [...] A culpa será a medida da responsabilidade, pois se o autor do dano agir com máxima precaução, o mesmo não será responsabilizado, ou, pelo menos, poderá ter a indenização reduzida equitativamente, nos termos do art. 944, parágrafo único, do Código Civil brasileiro". Também se observa um alargamento do nexo causal, pois o momento de análise é intensificado, abrangendo uma situação anterior ao dano efetivamente (FERREIRA, Keila Pacheco. Prevenção e responsabilidade civil: revisitando os aspectos teleológicos na primeira década do CC. In: LOTUFO, Renan; NANNI, Giovanni Ettore; MARTINS, Fernando Rodrigues (Org.). Temas relevantes do direito civil contemporâneo: reflexões sobre os 10 anos do Código Civil. São Paulo: Atlas, 2012. p. 721-722).

40 A pesquisa torna-se uma obrigação em face do princípio da precaução, bem como o dever de informação. Hartmann ressalta também que se deve fazer um amplo debate democrático sobre questões importantes ligadas ao princípio da precaução (HARTMANN, Ivar Alberto Martins. op. cit., p. 189-194).

41 Neste sentido, Levy aponta para uma diferenciação existente entre a punição e a prevenção, porém, esta diversidade de tratamento não impede que a punição seja utilizada como um instrumento de prevenção. Demonstrando esta instrumentalização da punição com função preventiva, o art. 1621 do Código Civil de Quebec apresenta a restrição dos punitive damages para o quantum necessário para se efetivar a prevenção: 
Sendo um tema importante e recorrente em obras recentes acerca da responsabilidade civil, dedicamos um espaço para abordar as críticas da função punitiva e os argumentos a favor de sua aplicação no direito civil brasileiro.

\subsubsection{A função punitiva}

O Direito Civil vem sofrendo uma reformulação de alguns conceitos e valores e a responsabilidade civil também, por consequência. Uma dessas mudanças da responsabilidade civil é a função punitiva, elencada como uma nova atuação do instituto. ${ }^{42}$

Existe o paradigma clássico e antigo da reparação integral o qual pugna pela indenização com base na extensão do dano sem qualquer acréscimo a título de punição do agente (função punitiva ou dissuasória). Entretanto, danos emergem na sociedade que são muito graves e que a necessidade de preveni-los é muito maior do que meramente indenizá-los posteriormente. ${ }^{43} \mathrm{Um}$ exemplo é o dano moral na internet.

Ademais, a função punitiva é ressaltada também nos casos em que o agente causa um dano com culpa grave ou dolo, ${ }^{44}$ suscitando o dever de punir essas condutas na sociedade.

Tendo em vista a variedade de argumentos relacionados à função punitiva, com fundamentação jurídica diversa entre si, cabe elucidá-los, apresentando também um posicionamento crítico sobre o tema. Mas, antecipamos já nossa tese no sentido de que é viável a função punitiva como instrumento de prevenção no direito civil brasileiro, porém,

"Where the awarding of punitive damages is provided for by law, the amount of such damages may not exceed what is sufficient to fulfill their preventive purpose" (Quando a indenização punitiva for prevista em lei, seu quantum não poderá exceder o montante suficiente para promover a prevenção do dano - Tradução livre) (LEVY, Daniel de Andrade. Responsabilidade civil: de um direito dos danos a um direito das condutas lesivas. São Paulo: Atlas, 2012. p. 127-128).

42 MORAES, Maria Celina Bodin de. Danos à pessoa humana: uma leitura civil-constitucional dos danos morais. Rio de Janeiro: Renovar, 2003. p. 67.

43 A dissertação de Serpa orienta-se no sentido de defender o fim do paradigma da reparação integral, ou seja, a função precípua de indenizar os danos com base na sua extensão, não havendo nenhum escopo punitivo. Com as alterações que marcaram o século XX e a emergência de novos danos e preocupações, a indenização punitiva aparece como instrumento de prevenção: “[...] inegavelmente, é muito salutar e eficiente prevenir a ocorrência de danos do que ter de atuar a posteriori, procurando restaurar uma situação lesiva já configurada (ainda mais em hipóteses como as aqui analisadas, nas quais os prejuízos tendem a se eternizar). É, portanto, justamente para o atingimento desse escopo principal (o de prevenir adequadamente o cometimento de condutas danosas aos interesses existenciais e metaindividuais) que se propugna, no presente trabalho, que se admita uma mitigação do paradigma ressarcitório da responsabilidade civil (na mesma medida que os desenvolvimentos contemporâneos do instituto operaram em relação aos demais paradigmas). Querse, com isso, que a responsabilidade civil possa exercer com eficiência essa função preventiva, que nos parece primordial para assegurar o equilíbrio social" (SERPA, Pedro Ricardo e. Indenização punitiva. 2011. Dissertação (Mestrado) - pela Faculdade de Direito, Universidade de São Paulo, São Paulo. p. 160).

44 CUNHA, Wladimir Alcibíades Marinho Falcão. Danos extrapatrimoniais e função punitiva. 2012. Tese (Doutorado) - Faculdade de Direito, Universidade de São Paulo, São Paulo. p. 12. 
ainda é necessária uma previsão legislativa que possa conferir legalidade a ela e resolver pontos não muito claros acerca de seu funcionamento.

A função punitiva vem sendo aplicada no Common Law, sendo que sua aplicação possui um histórico marcado por exageros, embora eles tenham diminuído ultimamente. Os critérios utilizados são a culpa grave, dolo, capacidade econômica do ofensor e da vítima, e a extensão do dano. Existem várias críticas sobre os punitive damages no sentido de que eles proporcionam o enriquecimento sem causa, tendo em vista que o montante indenizatório é punitivo e destinado para a própria vítima, violação ao princípio da legalidade, bis in idem, entre outras. ${ }^{45}$

Não pretendemos abordar os punitive damages, mas cabe ressaltar nosso entendimento de que a função punitiva deve ser aplicada de forma a impedir o enriquecimento sem causa, portanto, o montante vinculado à função punitiva não deve ser transferido à vítima, mas simplesmente aquela função ressarcitória, seguindo o entendimento de Serpa. ${ }^{46}$

O paradigma da reparação integral (art. 944, caput, do CC) sofre exceções. Uma delas consta no art. 944, parágrafo único, do CC, no qual está escrito que a indenização poderá sofrer uma diminuição caso haja uma desproporção entre a culpa e os danos causados. ${ }^{47}$

Ademais, os casos de danos extrapatrimoniais denotam situações em que o montante arbitrado pode não ser equivalente à extensão do dano, conforme pugna o paradigma da reparação integral.

Essas exceções ao princípio da reparação integral denotam que ele não é empecilho para a aplicação da função punitiva, conforme Ulian. ${ }^{48}$ De fato, a realidade

45 GUIMARÃES, Patrícia Carla Monteiro. Os danos punitivos e a função punitiva da responsabilidade civil. Direito e Justiça: Revista da Faculdade de Direito da Universidade Católica Portuguesa. v. 15, n. 1, p. 159206, 2001. p. 168-169.

46 SERPA, Pedro Ricardo e. op. cit., p. 202.

47 Levy aponta que houve a oportunidade para que a função punitiva da responsabilidade civil fosse prevista no Código Civil, mas, em sentido contrário, positivaram a limitação do quantum indenizatório com base na culpa. O Código Brasileiro de Telecomunicações e a Lei de Imprensa haviam legislado a reparação dos danos morais com critérios punitivos, mas, no Código Civil, não houve a previsão da punição no art. 944, parágrafo único, de modo que o entendimento prevalecente é de que é possível a redução do quantum indenizatório considerando a culpa do indivíduo e não seu aumento. O posicionamento do autor é igual ao entendimento prevalecente. (LEVY, Daniel de Andrade. Responsabilidade civil: de um direito dos danos a um direito das condutas lesivas. São Paulo: Atlas, 2012. p. 70-71). Em contrapartida, há o entendimento de que o art. 944, CC não retira a viabilidade da indenização punitiva, externado no Enunciado n. 379, da IV Jornada de Direito Civil: "O art. 944, caput, do Código Civil não afasta a possibilidade de se reconhecer a função punitiva ou pedagógica da responsabilidade civil”.

48 ULIAN, Eduardo. Responsabilidade civil punitiva. 2003. Tese (Doutorado) - Faculdade de Direito, Universidade de São Paulo, São Paulo. p. 64. Com um pensamento próximo, Ferreira argumenta que a necessidade de se compensar danos não passíveis de quantificação exata já denota um enfraquecimento do paradigma da reparação integral. Neste contexto, ela diz que outro critério teria de ser utilizado também no 
vivida demonstra situações nas quais a culpa deve ser considerada para majorar as indenizações. Outrossim, o princípio da reparação integral não fornece respostas às exigências de prevenção e de precaução, ou seja, não há nenhum estímulo à tomada de cautela.

O histórico dos danos morais no direito brasileiro possui uma relação próxima com a função punitiva da responsabilidade civil. Havia um argumento da doutrina católica no sentido de que era imoral indenizar uma pessoa com a finalidade de reparar danos morais. Assim, para afastar a incidência desta crítica e propiciar a indenização, desenvolveu-se a tese de que a finalidade da reparação do dano moral não era compensar uma "dor"; mas, sim, de punir o ofensor. Dessa forma, estes pontos de argumentação explicam o motivo para o argumento de que a reparação do dano moral possui um viés punitivo. $^{49}$

Em um movimento contrário aos argumentos acima, desenvolveu-se uma corrente que sustentava a função simplesmente compensatória da reparação por danos morais porque a pena seria algo muito duro e intenso para o agente.

Vê-se, portanto, que a reparação por danos morais envolveu historicamente as funções compensatória e punitiva. ${ }^{50}$

Ressaltamos que a função punitiva da responsabilidade civil deve ser aplicada somente nos casos de danos graves, como os ilícitos lucrativos, ${ }^{51}$ os danos morais na internet e os danos coletivos ( $v . g$., o dano ambiental).

As microlesões configuram outra hipótese de aplicação. Trata-se de lesões cuja reparação seria de valor ínfimo, de modo que não seria vantajoso ajuizar ação pedindo sua reparação. Dessa forma, ante a posição vantajosa para o autor do dano, seria o caso

arbitramento, e ele é o critério da culpa (FERREIRA, Keila Pacheco. Prevenção e responsabilidade civil: revisitando os aspectos teleológicos na primeira década do CC. In: LOTUFO, Renan; NANNI, Giovanni Ettore; MARTINS, Fernando Rodrigues (Org.). Temas relevantes do direito civil contemporâneo: reflexões sobre os 10 anos do Código Civil. São Paulo: Atlas, 2012. p. 708).

49 LEVY, Daniel de Andrade. Responsabilidade civil: de um direito dos danos a um direito das condutas lesivas. São Paulo: Atlas, 2012. 46.

50 LEVY, Daniel de Andrade. op. cit., p. 44 e ss. Cunha explica que a punição na responsabilidade civil está presente neste movimento desempenhado pelos danos morais, nas discussões a respeito da função punitiva; na presença da aplicação da pena privada na Itália (Gallo) e França (Hugueney, Demogue e Starck), bem como na common law (CUNHA, Wladimir Alcibíades Marinho Falcão. 2012. Danos extrapatrimoniais e função punitiva. Tese (Doutorado) - Faculdade de Direito, Universidade de São Paulo, São Paulo. p. 57). Neste sentido, entende que os punitive damages podem ser inseridos no ordenamento jurídico brasileiro.

51 ANDRADE, André Gustavo Corrêa. Dano moral e indenização punitiva. 2. ed. rev. e atual. Rio de Janeiro: Lumen Juris, 2009. p. 246-248. Os defensores da função punitiva sustentam a aplicação dela em situações em que haja dolo e culpa grave, associando as situações com casos de aplicação dos punitive damages. Não temos o intuito de analisar as variadas hipóteses de aplicação da função punitiva defendidas e propostas, mas, pretendemos expor uma situação nova que é do dano moral cometido na internet, que será visto detalhadamente nos capítulos posteriores. 
de fornecer indenização punitiva nas reparações para propiciar a função preventiva neste caso. $^{52}$

A função punitiva é apontada como um instrumento de prevenção quando outras medidas não forem eficazes ou tiverem eficácia diminuta. ${ }^{53}$

$\mathrm{Na}$ indenização por danos morais, a jurisprudência aplica a função punitiva. ${ }^{54}$ Neste contexto, Ulian sustenta que a punição do agente pode ocorrer mediante a compensação dos danos ou mediante a pena privada. ${ }^{55}$

Discordamos deste posicionamento porque a compensação dos danos apenas considera elementos inerentes ao próprio dano e não características atinentes ao agente e à sua conduta, como ocorre com a indenização punitiva.

Ademais, cumpre salientar que a função punitiva deve ser aplicada mediante a separação de quantum reparatório e punitivo, de modo que apenas o primeiro seria destinado à vítima, evitando enriquecimento sem causa desta, e o quantum destinado à punição é transferido a um fundo em contribuição com a sociedade, assumindo o escopo social da função punitivo-preventiva. Assim, é indispensável que o causador do dano saiba o montante de punição que deverá pagar. Somente tendo ciência da punição sofrida é que o caráter preventivo e desestimulador ocorrerá e também se evitará o enriquecimento sem causa da vítima, assumindo como premissa o deslocamento do montante punitivo para um fundo social. Importante ressaltar que a fundamentação jurídica, os motivos colocados e a argumentação do juiz são pontos cruciais que, juntamente com o quantum diferenciado e punitivo, contribuirão com a eficácia preventiva da indenização.

A jurisprudência brasileira apenas fundamenta o quantum na função punitiva, mas não separa os montantes compensatório e punitivo, sendo que não há

52 LEVY, Daniel de Andrade. op. cit., p. 104-105. As microlesões diferenciam-se dos danos coletivos. Elas são importantes para prevenção porque o autor dos danos está se beneficiando com o não ajuizamento proporcional de ações civis. Os danos coletivos afetam a sociedade inteira, não sendo possível diferenciar o dano coletivo em microlesões. Ademais, nos casos abrangidos por responsabilidade objetiva, o autor entende que a vítima não necessita provar a culpa do ofensor para haver a aplicação da função punitiva, pois seria um grande encargo para ela.

53 ANDRADE, André Gustavo Corrêa. op. cit., p. 228 e ss.

54 ULIAN, Eduardo. Responsabilidade civil punitiva, Tese de doutorado pela Faculdade de Direito da Universidade de São Paulo, 2003, p. 11 e ss. CUNHA explica que parcela majoritária da doutrina entende que a reparação por danos morais possui função punitiva (CUNHA, Wladimir Alcibíades Marinho Falcão. Danos extrapatrimoniais e função punitiva. 2012. Tese (Doutorado) - Faculdade de Direito, Universidade de São Paulo, São Paulo. p. 53). No mesmo sentido, MARINANGELO, Rafael. A evolução da indenização por dano moral e a aplicação da indenização punitiva. In: LOTUFO, Renan; NANNI, Giovanni Ettore; MARTINS, Fernando Rodrigues (Org.). Temas relevantes do direito civil contemporâneo: reflexões sobre os 10 anos do Código Civil. São Paulo: Atlas, 2012. p. 682.

55 ULIAN, Eduardo. op. cit., p. 14. 
realmente a aplicação da função punitiva, mas mera argumentação que evite o denominado enriquecimento sem causa e que explica o quantum arbitrado. ${ }^{56}$

Marinangelo sustenta uma tese semelhante:

Ocorre, porém, que embora haja este reconhecimento do caráter punitivo da indenização por danos morais, sua aplicação é apenas subsidiária e limita-se mais ao campo teórico do que prático. Com efeito, é possível vislumbrar inúmeras referências ao caráter do dano moral nos julgados das cortes brasileiras, porém, o que se verifica, na prática, é que a suposta punição não aparece de modo claro na quantificação do valor indenizatório e, na grande maioria das vezes, sucumbe diante do receio do pretenso enriquecimento sem causa da vítima. ${ }^{57}$

O mesmo autor ressalta que a função punitiva não é aplicada igual aos punitive damages, em que a punição não é associada à compensação de danos, mas, sim, ao comportamento lesivo do agente. O que ocorre, na jurisprudência, é uma combinação de critérios para justificar o quantum e a inexistência de enriquecimento sem causa. ${ }^{58}$

Nosso entendimento é semelhante. A função punitiva não procura reparar o dano, mas fornecer um desestímulo, uma prevenção baseada na majoração do quantum a ser pago pelo causador do prejuízo. O juiz deve fixar o quantum punitivo de forma apartada do montante com função indenizatória, ou seja, haveria dois montantes com funções e destinações distintas.

Diversamente de como a jurisprudência entende, o quantum punitivo não tem a vítima como destinatária, mas a sociedade representada por um fundo público, ou seja, se a prevenção dos danos, que possui notável interesse público intrínseco, é a finalidade, a destinação do quantum punitivo-preventivo não será a vítima, mas um fundo social. Caso contrário, estaríamos diante de um enriquecimento sem causa.

56 MARINANGELO, Rafael. op. cit., p. 685-686.

57 Ibid., p. 684. Schreiber critica argumentando que a jurisprudência tende a utilizar critérios para arbitrar indenizações para casos que devem ter tratamentos diferentes, seguindo as características peculiares de cada um. Além disso, ele ressalta a impossibilidade de se juntar a função compensatória e a função punitiva na mesma indenização, ou seja, "o resultado é que as decisões judiciais tratam de forma unitária quantias atribuídas a títulos inteiramente diversos, fundados em fatos e argumentos distintos. Torna-se impossível, no cenário brasileiro, separar no valor da condenação a parcela concedida a título de compensação do dano e aquela que se pretende atribuir à vítima a título de punição do ofensor. Há, nisto, violação flagrante ao direito de ampla defesa do causador do dano e limitação ao contraditório em sede de recurso, já que se inviabiliza a discussão acerca da legalidade e conveniência da punição, cuja extensão nem chega a ficar clara" (SCHBEIRER, Anderson. Arbitramento do dano moral no Novo Código Civil. Revista Trimestral de Direito Civil, Rio de Janeiro, v. 12, out./dez. 2002. p. 20).

58 MARINANGELO, Rafael. op. cit., p. 685-686. 
No momento de se arbitrar o montante punitivo, a atenção do magistrado volta-se para o comportamento do agente, porque o fundamento é evitar danos e os critérios baseiam-se exclusivamente na causa lesiva.

Uma situação em que Andrade insere a possibilidade de aplicação da função punitiva é aquela na qual o agente aufere um benefício econômico decorrente de sua atividade. Um ganho patrimonial que serve como incentivo para a continuidade da prática lesiva. ${ }^{59}$

Neste sentido, Benacchio sustenta que, diante de prática lesiva corroborada com um ganho patrimonial auferido pelo agente, a responsabilidade civil sem a função punitiva seria insuficiente para tratar essas situações e a responsabilidade penal seria um instrumento desproporcional, sendo inviável sua aplicação. ${ }^{60}$

A primeira ideia que se tem quando se fala de punição é o Direito Penal ou o Direito Administrativo Sancionador, por isso é que a defesa da indenização punitiva no Direito Civil torna-se um aspecto controvertido entre os autores, mas há seus defensores que veem a necessidade e a importância de sua aplicação no Direito brasileiro.

O Direito Privado não está distante do Direito Público, de modo que há uma comunicação entre eles, não sendo sistemas fechados e incomunicáveis entre si. A partir dessa comunicação é que há um novo panorama para a responsabilidade civil. ${ }^{61}$

Existe a tendência de despenalização de condutas pelo Direito Penal pelo fato de este não desejar abranger várias condutas e, também, por não ter muita eficácia. Ademais, observa-se que o avanço da sociedade provocou a ocorrência de situações não abrangidas nem tuteladas pelo Direito Penal. ${ }^{62} \mathrm{O}$ resultado deste movimento é o crescimento da responsabilidade civil em relação à tutela penal, de modo que a reparação dos danos causa a extinção da responsabilidade penal.

Seja porque jamais foram preenchidos, seja porque já não existe conteúdo normativo suficiente para preenchê-los, fato é que, cada vez mais, vemos condutas ilícitas ficarem à mercê de uma sanção puramente civil. Some-se a isso um movimento de despenalização de certas condutas sobre as quais o sistema punitivo clássico já não tem - e não quer ter - mais qualquer eficácia. ${ }^{63}$

59 ANDRADE, André Gustavo Corrêa. Dano moral e indenização punitiva. 2. ed. rev. e atual. Rio de Janeiro: Lumen Juris, 2009. p. 228 e ss.

60 BENACCHIO, Marcelo. A função punitiva na responsabilidade civil no Código Civil. In: LOTUFO, Renan; NANNI, Giovanni Ettore; MARTINS, Fernando Rodrigues (Org.). Temas relevantes do direito civil contemporâneo: reflexões sobre os 10 anos do Código Civil. São Paulo: Atlas, 2012. p. 651.

${ }^{61}$ ANDRADE, André Gustavo Corrêa. op. cit., p. 230.

${ }_{62}$ Neste sentido, AZEVEDO, Antonio Junqueira de. Por uma nova categoria de dano: o dano social. In: Novos estudos e pareceres de direito privado. São Paulo: Saraiva, 2009. p. 379.

63 LEVY, Daniel de Andrade. Responsabilidade civil: de um direito dos danos a um direito das condutas 
Como resultado, duas tendências convergem-se: de um lado observa-se o interesse do Direito Penal de que a reparação dos danos seja a solução para alguns delitos penais; de outro lado, há o fato de que o Direito Penal tomou para si a proteção de interesses que não consegue proteger de modo eficaz. Assim, observa-se um movimento de penalização da responsabilidade civil e um movimento de despenalização do Direito Penal.

Para exemplificar essas aproximações e comunicações entre o Direito Penal e o Direito Civil, existem dispositivos do Código Penal em que a reparação dos danos, aspecto da própria responsabilidade civil, gera efeitos no Direito Penal. O dispositivo no art. 16 do $\mathrm{CP}$, que, em relação aos crimes cometidos sem violência ou grave ameaça à pessoa, inclui a reparação do dano como causa geral de diminuição da pena, configurando arrependimento posterior. A reparação do dano também constitui circunstância atenuante, nos termos do art. 65, inciso III, alínea b, do CP. É condição para o livramento condicional (art. 83, IV, do CP); requisito para a reabilitação (art. 94, III, do CP); exigência para a concessão do sursis (art. 81, II, do CP); dá ensejo à extinção de punibilidade do crime de peculato culposo (art. 312, $\S 2^{\circ}$, do CP). ${ }^{64}$

Da mesma forma, há influência do Direito Penal no Direito Civil de modo que dispositivos do Código Civil preveem hipóteses de punições (92), como nos casos dos arts. 766, 768, 769, 773, 939, 940, de arras, cláusula penal, restituição em dobro (art. 42, parágrafo único, CDC), juros de mora e a Lei n. 8.245/1991. ${ }^{65}$ Ambos não constituem ramos estanques e isolados:

Os influxos de um ramo do Direito no outro são evidentes, demonstrando que a separação entre Direito Penal e Direito Civil é mais de ordem metodológica ou didática do que lógico-jurídica. Essa divisão ou ramificação do Direito não constitui, portanto, argumento válido contra a ideia de pena privada como forma de reação jurídica ou sanção para certos ilícitos civis de maior gravidade. ${ }^{66}$

lesivas. São Paulo: Atlas, 2012. p. 119 e ss.

64 ANDRADE, André Gustavo Corrêa. op. cit., p. 231. Demonstrando seu entendimento e sua tese sobre o assunto, Levy afirma: "Impossível não pensar na indenização punitiva como uma nova via do contencioso, sob a égide de uma função normativa da Responsabilidade Civil. O debate acerca do papel a ser desempenhado pelo Direito Penal nos mostra que a indenização punitiva não é apenas o fruto temporário e paliativo que substitui uma disciplina em franca contestação; muito pelo contrário, reflete uma vontade, mesmo dos penalistas, de transferir para uma lógica reparadora (rectius, resolutiva), a tutela de bens patrimoniais. Ousamos afirmar que a despenalização do setor público não é contraditória com a extensão das penas privadas, como afirmou De Cupis, mas complementar, pois enquanto a lógica se imiscuirá na repressão dos ilícitos materiais, poderá a disciplina penal se concentrar sobre ilícitos pessoais" (LEVY, Daniel de Andrade. Responsabilidade civil: de um direito dos danos a um direito das condutas lesivas. São Paulo: Atlas, 2012. p. 122).

65 Neste sentido, também ULIAN, Eduardo. op. cit., p. 5.

${ }_{66}$ ANDRADE, André Gustavo Corrêa. Dano moral e indenização punitiva. 2. ed. rev. e atual. Rio de Janeiro: 
Nos danos coletivos e transindividuais, observa-se também que a função punitiva está presente, devido aos interesses da dissuasão do ofensor e da intensidade do dano.

Ulian $^{67}$ argumenta a convivência da responsabilidade civil com o Direito Penal e o Direito Administrativo Sancionador com o objetivo de fornecer respostas para as condutas indesejáveis pela sociedade. Problemas intrínsecos ao Direito Penal e ao Direito Administrativo Sancionador seriam óbices para uma maior eficácia punitiva e preventiva, tornando necessária a integração com a responsabilidade civil. ${ }^{68}$

A burocracia do Direito Administrativo e a falta de eficiência do processo penal com suas várias fases são problemas apontados pelo autor:

\begin{abstract}
Assim, os procedimentos investigatórios, as fiscalizações e a atuação em processo judicial são operações que demandam investimentos e uma atuação, nem sempre eficiente, do corpo de servidores que atua na prevenção e na repressão das condutas danosas. Ademais, o Direito Administrativo estaria marcado pela parcialidade que impede a aplicação de medidas sancionadoras que, conforme o autor, podem ser revogadas pela aplicação do "princípio da inafastabilidade da jurisdição. ${ }^{69}$
\end{abstract}

Amaral explica que o Direito Penal passa por um processo de deslegitimação, marcado por vários fatores, que ele elenca: a) A pena privativa de liberdade "representa uma violência institucional", exigindo um esforço de legitimação. O autor ainda comenta que a pena privativa de liberdade tem se revelado de menor eficácia; b) Os órgãos e instituições persecutores penais não tutelam interesses da sociedade e da coletividade, mas apenas de alguns grupos; c) "O funcionamento da justiça penal é altamente seletivo, porque ao

Lumen Juris, 2009. p. 234.

67 ULIAN, Eduardo. op. cit., p. 2.

68 Serpa também afirma a maior flexibilidade da responsabilidade civil em comparação com o processo existente no Direito Penal e no Direito Administrativo. Tanto o Direito Penal como o Direito Administrativo respeitam o princípio da legalidade, baseado no brocardo nullum crimen nulla poena sine lege. O Direito Civil também respeita o princípio da legalidade, mas há uma diferença, segundo SERPA. O direito privado possui cláusulas gerais e uma forma de tipificar a responsabilidade civil de modo que é mais flexível do que o Direito Penal e o Direito Administrativo. Conforme o autor há o uso de "conceito indeterminados" e de "cláusulas gerais", que demonstram uma abrangência maior da responsabilidade civil (SERPA, Pedro Ricardo e. Indenização punitiva. 2011. Dissertação (Mestrado) - Faculdade de Direito, Universidade de São Paulo, São Paulo. p. 163-164). Levy explica que a responsabilidade civil vem canalizando a importância de proteção do indivíduo ao longo da evolução da sociedade e do Direito, principalmente no século XXI. Ao lado dessa proteção, há o fato de que a solidariedade também é outro elemento que influencia a responsabilidade. Neste contexto, a insatisfação das pessoas em relação ao Direito Penal e Direito Administrativo, a facilidade de acesso ao Poder Judiciário contribuem para a expansão da responsabilidade civil (LEVY, Daniel de Andrade. op. cit., p. 24-27).

69 ULIAN, Eduardo. op. cit., p. 2. 
proteger bens e interesses intervém diretamente no processo de seleção e recrutamento da clientela do sistema, como resulta evidente pelo exame da população carcerária"; d) O sistema penal não resolve os problemas antes de puni-los; e) A organização do sistema penal hoje não provoca uma defesa social atrelada à teoria dos fins da pena; f) Há uma expansão do Direito Penal para tutelar bens difusos e funções, com o intuito para antecipar a tutela penal; ${ }^{70} \mathrm{~g}$ ) $\mathrm{O}$ fato de o direito penal se levar por clamor público, principalmente influenciada pela mídia, provoca a desconsideração dos princípios da fragmentariedade e da subsidiariedade, e do caráter de ultima ratio no direito penal e; h) O Direito Penal tem sido o instrumento do Estado para regular os efeitos e riscos derivados da crescente especialização do desenvolvimento tecnológico. ${ }^{71}$

Denota-se uma flexibilidade na responsabilidade civil que a diferencia da responsabilidade penal. Enquanto que o processo penal e o processo de responsabilidade penal devem obedecer aos princípios da taxatividade, intervenção mínima ${ }^{72}$ e ao da legalidade, não podendo haver a responsabilidade penal em situação não prevista em lei, a responsabilidade civil mostra-se mais flexível, não havendo uma normatização extensa acerca de seu funcionamento. ${ }^{73}$

70 "O favorecimento pela adoção de formas de tutela antecipada é da própria estrutura da tutela dos interesses difusos e das funções respectivas, com a consequente diminuição do status de cidadão para todos os envolvidos no fenômeno criminal: delinquente, vítima e terceiros" (AMARAL, Claudio do Prado. Despenalização pela reparação de danos: a terceira via. Leme: J. H. Mizuno, 2005. p. 120).

71 Ibid., p. 119-120. A crise do direito penal é o motivo para se buscar outros meios de intimidação e de prevenção dos danos. Assim, entra a teoria do autor: aplicação da reparação dos danos como terceira via, ao lado das penas e das medidas de segurança. Guimarães também critica o Direito Penal, embora seu ponto de vista não seja o direito brasileiro, mas o português (GUIMARÃES, Patrícia Carla Monteiro Guimarães. Os danos punitivos e a função punitiva da responsabilidade civil. Direito e Justiça: Revista da Faculdade de Direito da Universidade Católica Portuguesa, v. 15, n. 1, p. 159-206, 2001. p. 167).

72 Costa e Pargendler ressaltam que a presença da pena privada na responsabilidade civil deu-se devido à ineficácia da prevenção por meio da reparação dos danos. Ademais, o Direito Penal relaciona-se a condutas mais graves, possibilitando que a responsabilidade civil possa aplicar a função punitiva em condutas menos gravosas (COSTA, Judith Martins; PARGENDLER, Mariana Souza. Usos e abusos da função punitiva. Revista CEJ/Conselho da Justiça Federal, Brasília: CEJ, v. 9, n. 28, jan/mar. 2005. p. 21).

73 ULIAN, Eduardo. op. cit., p. 74 e ss. No mesmo sentido, BENACCHIO, Marcelo. A função punitiva na responsabilidade civil no Código Civil. In: LOTUFO, Renan; NANNI, Giovanni Ettore; MARTINS, Fernando Rodrigues (Org.). Temas relevantes do direito civil contemporâneo: reflexões sobre os 10 anos do Código Civil. São Paulo: Atlas, 2012. p. 668. Levy possui o mesmo entendimento acerca do papel crescente da responsabilidade civil ao lado da burocracia no acesso à tutela penal e administrativa e diz que a responsabilidade civil assume o ponto principal no que concerne à proteção dos indivíduos: "Daí advém a Responsabilidade Civil como expediente de controle social, canalizando as insatisfações resultantes do dano, verdadeira regulação difusa das condutas. A facilidade de acesso ao Poder Judiciário e os mecanismos relativamente simples da disciplina, por oposição às estruturas engessadas de disciplinas sancionatórias como o Direito Administrativo ou o Direito Penal, apenas corroboram esse fenômeno de expansão" (LEVY, Daniel de Andrade. Responsabilidade civil: de um direito dos danos a um direito das condutas lesivas. São Paulo: Atlas, 2012. p. 27). 
Embora haja uma aproximação das responsabilidades civil e penal, ambas possuem funções específicas e campos delimitados. A responsabilidade penal ficou reservada aos ilícitos (penais) de maior gravidade, enquanto que a responsabilidade civil ficou reservada a outros ilícitos. ${ }^{74}$

Schreiber e Tepedino suscitam críticas a respeito dessas supostas hipóteses de punição no Código Civil. No que concerne à cobrança indevida de dívida já paga e cobrança maior de dívida (arts. 939 e 940, CC), explicam os autores que os dispositivos em análise constituem um comportamento do legislador já presente no Código Civil de 1916. Uma prática que visava reparar danos relacionados à honra ou a danos à personalidade que não eram protegidos nem tutelados pelo Direito na época.

De fato, como não eram consideradas indenizáveis as consequências da lesão à personalidade humana, em seus múltiplos aspectos, o legislador de 1916 estipulava, neste caso, uma pena privada para o infrator. O mesmo expediente era empregado, no ordenamento brasileiro, em outro caso de lesão à personalidade humana, qual seja, o de ofensa à saúde. ${ }^{75}$

Com base no exposto, concluem que o aspecto punitivo destes dispositivos é questionável porque pode se tratar de um mecanismo do próprio Direito de reparar os danos da personalidade numa situação de irreparabilidade dos danos morais, no contexto jurídico brasileiro. "Tais normas possuem, em síntese, uma estrutura de pena privada, mas sua função não necessariamente deve ser considerada punitiva" ${ }^{76}$

Outro caso apontado de pena privada é no condomínio edilício, nos arts. 1336 e 1337, CC. A mera imposição de penas ao quíntuplo ou ao décuplo do valor da contribuição já seria suficiente para demonstrar a pena privada. O legislador deixou mais claro ao dizer que a multa será aplicada independente das perdas e danos. Os autores explicam que embora a participação do juiz não seja certa, observa-se que os atos privados são sujeitos à revisão com base nos valores constitucionais. ${ }^{77}$

Um ponto de desajuste em relação à suposta pena privada presente nesses artigos seria o fato de que o adquirente do imóvel paga pelas multas do proprietário

\footnotetext{
74 BENACCHIO, Marcelo. op. cit., p. 653.

75 SCHREIBER, Anderson; TEPEDINO, Gustavo. As penas privadas no direito brasileiro. In: SARMENTO, Daniel; GALDINO, Flavio. Direitos fundamentais: estudos em homenagem Ricardo Lobo Torres. Renovar: Rio de Janeiro, 2006. p. 504.

76 SCHREIBER, Anderson; TEPEDINO, Gustavo. As penas privadas no direito brasileiro. In: SARMENTO, Daniel; GALDINO, Flavio. Direitos fundamentais: estudos em homenagem Ricardo Lobo Torres. Renovar: Rio de Janeiro, 2006. p. 505.

77 Ibid., p. 506-508.
} 
anterior. Sendo que a pena é intransferível a outro, o dispositivo presente no art. 1.345 está equivocado:

Cuidando-se de sanção de caráter penal, e não ressarcitório, deveria permanecer na esfera daquele que incorre na conduta apenada, excluindo-se sua transmissão a outrem, ainda que na qualidade de sucessor de sua titularidade dominical. A transmissão somente se justificaria nos casos em que o legislador atribuísse à multa valor meramente ressarcitório de eventuais danos derivados da conduta indesejada do devedor. ${ }^{78}$

Outra hipótese de sanção punitiva inserida trata-se da revogação de doação por ingratidão do donatário (art. 557, CC). Outra hipótese é do art. 1814, CC (exclusão da sucessão hereditária por indignidade do herdeiro). Ademais, há a hipótese de exclusão da associação conforme o art. 57, CC.

Segundo os autores, o exame de cada dispositivo revela peculiaridades de cada um. Na revogação da doação, a proteção é somente para o doador. Na exclusão da sucessão hereditária, a proteção dirige-se para os outros herdeiros e o de cujus.

Em ambos os casos, entretanto, não se mostra incontestável que o objetivo do legislador tenha sido o de impor ao donatário, ao herdeiro ou ao legatário uma penalidade adicional àquela que o ordenamento já lhe reserva por meio do direito penal. ${ }^{79}$

Os autores defendem que a sanção vincula-se também a uma situação de "inequidade" em que o doador estaria submetido à liberalidade a quem fez algo contra ele. $\mathrm{O}$ que acontece também no caso da herança, em que parte da herança estaria vinculada àquele que causou algo contra o de cujus. ${ }^{80}$

Quanto à exclusão do associado, os autores observam que o caráter punitivo está ainda mais distante. A conduta antissocial não está tipificada e que a exclusão do associado não está vinculada à punição do agente. Ademais, os fins perseguidos pelas hipóteses mencionadas e os requisitos são diferentes entre si. Enquanto que a gravidade da conduta está presente na revogação da doação, a exclusão do associado exige uma “justa causa”, que é uma expressão aberta, que não necessariamente dizem respeito a um comportamento malicioso ou doloso. A forma também se diferencia. A exclusão do

\footnotetext{
78 SCHREIBER, Anderson; TEPEDINO, Gustavo. As penas privadas no direito brasileiro. In: SARMENTO, Daniel; GALDINO, Flavio. Direitos fundamentais: estudos em homenagem Ricardo Lobo Torres. Renovar: Rio de Janeiro, 2006. p. 508.

79 Ibid., p. 510.

$80 \quad$ Ibid., p. 510.
} 
herdeiro dá-se por sentença judicial enquanto que a exclusão do associado dá-se por ato privado. $^{81}$

Os autores explicam que a possível relação entre a cláusula penal e a pena privada. Preliminarmente, vê-se que o caráter punitivo é controverso. A maior parte da doutrina entende que a cláusula penal tem o caráter compensatório e o caráter punitivo. ${ }^{82}$

Os autores começam a explicação para mostrar o arrefecimento do caráter punitivo da cláusula penal. O primeiro dispositivo é o art. 413, CC, que já tinha uma prévia no art. 924, CC de 1916. Seria um “favor debitoris" porque impediria o enriquecimento sem causa do credor. Os autores explicam que havia cláusulas contratuais que retiravam a possibilidade do juiz corrigir, mas com o tempo, entendeu-se que se trata de uma norma de ordem pública, tendo um caráter social. ${ }^{83}$

Tem-se, assim, que o dever de redução equitativa da cláusula penal, associado a outros limites e mecanismos de controle da autonomia privada presentes no ordenamento jurídico, permitem constatar que a cláusula penal, embora prescinda, por sua própria finalidade, de exata correspondência com o valor do prejuízo, não dispensa a análise funcional que tome em consideração o dano efetivamente provocado - e não o inadimplemento - como seu elemento justificador. ${ }^{84}$

Com base nessa argumentação, comentam que a cláusula penal atrela-se ao dano, tem uma correlação. Neste sentido, não há um caráter penal da cláusula penal, retirando o caráter duplo de compensação e punição da cláusula penal:

Daí inclinar-se a doutrina mais recente à rejeição da função punitiva da cláusula penal compensatória e à proposta de uma nova tipologia para a cláusula penal que distinga, com precisão, as cláusulas de função punitiva ou sancionatória daquelas de liquidação antecipada do dano, destinadas a pré-fixar o montante da indenização. ${ }^{85}$

Neste sentido, a função punitiva seria atrelada somente a essas cláusulas penais com intuito punitivo. Em contrapartida, haveria dificuldade de separar e distinguir as espécies de cláusula penal. A outra dificuldade seria de ver se há outras formas de

81 SCHREIBER, Anderson; TEPEDINO, Gustavo. As penas privadas no direito brasileiro. In: SARMENTO, Daniel; GALDINO, Flavio. Direitos fundamentais: estudos em homenagem Ricardo Lobo Torres. Renovar: Rio de Janeiro, 2006. p. 510.

82 Ibid., p. 511.

83 SCHREIBER, Anderson; TEPEDINO, Gustavo. As penas privadas no direito brasileiro. In: SARMENTO, Daniel; GALDINO, Flavio. Direitos fundamentais: estudos em homenagem Ricardo Lobo Torres. Renovar: Rio de Janeiro, 2006. p. 512.

$84 \quad$ Ibid., p. 513.

85 Ibid., p. 513. 
punição, como as arras penitenciais. Por fim, seria necessário ligar o aspecto funcional de todas as espécies de punição. ${ }^{86}$

Há uma diversidade das astreintes apontadas como penas privadas. Algumas funcionam como pena privada, mas a função é proteger um interesse público e outras procuram proteger um interesse privado. ${ }^{87}$

Defende-se por vezes penas privadas cuja origem seja no sujeito de direito privado e não sendo produto da atividade legislativa. De outro modo, sustenta-se também sanções privadas cuja origem é legislativa ou judicial. Este caso seria o da astreinte (multa diária).

Ela não está regulada no Código Civil, mas no Código Processual Civil, nos arts. 644 e 645. Segundo os autores, há um limite para a multa diária definido na jurisprudência como sendo o mesmo pela cláusula penal (art. 412, CC), porém, não há um limite explícito no ordenamento jurídico. ${ }^{88}$

Schreiber e Tepedino mostram incoerências, idas e vindas, a respeito da multa diária e seus limites impostos pela jurisprudência. Desta forma, ele diz que "A indefinição jurisprudencial revela, na verdade, um problema subjacente e anterior à discussão dos limites das astreintes: o da sua própria função". ${ }^{89}$

Por sua vez, a doutrina é unânime em dizer que a função principal da multa diária é a compensação, não havendo necessariamente, o caráter punitivo. Procura-se coagir o devedor a cumprir a obrigação. A multa diária sanciona a inércia sanável do devedor. ${ }^{90}$

Ela se diferencia das outras modalidades de punição, como com a revogação da doação, em que não há um intuito coercitivo:

Em outros termos, as astreintes, se possuem um caráter punitivo, não o apresentam com a mesma intensidade ou da mesma forma que as demais figuras ditas de pena privada. A própria natureza privadas das astreintes é questionável; não apenas sua fonte é a autoridade judiciária, mas sua aplicação tutela inegavelmente um interesse público. ${ }^{91}$

${ }_{86}$ SCHREIBER, Anderson; TEPEDINO, Gustavo. As penas privadas no direito brasileiro. In: SARMENTO, Daniel; GALDINO, Flavio. Direitos fundamentais: estudos em homenagem Ricardo Lobo Torres. Renovar: Rio de Janeiro, 2006. p. 514.

87 Ibid., p. 515.

88 Ibid., p. 515-516.

89 Ibid., p. 517.

90 Ibid., p. 517-518.

91 SCHREIBER, Anderson; TEPEDINO, Gustavo. As penas privadas no direito brasileiro. In: SARMENTO, Daniel; GALDINO, Flavio. Direitos fundamentais: estudos em homenagem Ricardo Lobo Torres. Renovar: Rio de Janeiro, 2006. p. 518. 
Embora haja posicionamentos diversos como os anteriores, a presença das punições no ordenamento jurídico é efeito de uma adaptação às exigências sociais, que clamaram por uma proteção maior. No cotidiano, existem danos cuja ocorrência se deu dentro de uma atividade lícita, sem haver descumprimento de padrões de conduta e foi neste contexto que houve o desenvolvimento da teoria do risco. Em outras situações danosas, não houve uma conduta que destoa muito dos padrões de conduta, sendo, portanto, uma falta jurídica leve ou levíssima. Por fim, existem aqueles casos em que as ofensas e os danos foram resultados de uma conduta completamente querida no dolo do autor do dano. ${ }^{92}$

Mostrando essas situações, é natural que se as puna diferentemente, com base na culpa de cada uma. "Nesse prisma, seria justo apenas com mais rigor um ato maléfico do que outro ato apenas minimamente culposo. E isso mesmo que os danos provocados fossem rigorosamente iguais". ${ }^{93}$ Dessa forma, a análise da culpa é importante e crucial para a consideração de cada tipo de dano e de conduta. Ela só foi afastada por uma necessidade de proteção da própria vítima, nos casos de responsabilidade objetiva.

Percebe-se, dessa maneira, que apesar de a culpa ter sido afastada com o desenvolvimento da responsabilidade civil, ela não foi esquecida e deve orientar a responsabilidade civil em diversas condutas.

É dizer, as diferenças de culpas, os graus de culpa, mesmo os tipos de dolos, não chegaram a ser expurgados da essência da responsabilidade civil, e, com eles, também ao desejo de puni-los, sancioná-los, atribuir-lhe responsabilidades, censurá-los desigualmente justamente conforme o grau da conduta, o que se mostra mais e mais verdadeiro numa sociedade plural de múltiplos riscos e múltiplos danos como a atual. ${ }^{94}$

Para o exercício de uma função preventiva na responsabilidade civil, é imperioso que haja meios de impor uma influência no comportamento privado. Aquele agir lesivo deve ser influenciado e alterado, no sentido de ser desestimulado a causar novos danos. A efetividade deste pensamento não ocorre se a responsabilidade civil permanecer atrelada somente na reparação dos danos..$^{95}$

Neste sentido, a presença de um fator novo para incidir sobre o comportamento dos autores é relevantíssimo e ele caracteriza-se pela punição na

\footnotetext{
92 CUNHA, Wladimir Alcibíades Marinho Falcão. Danos extrapatrimoniais e função punitiva. 2012. Tese (Doutorado) - Faculdade de Direito, Universidade de São Paulo, São Paulo. p. 134.

93 Ibid., loc. cit.

94 Ibid., p. 135.

$95 \quad$ No mesmo sentido, Ibid., p. 136.
} 
responsabilidade civil. Conforme essa base argumentativa, Cunha sustenta a punição como um princípio interpretativo ou um princípio ético-jurídico da responsabilidade civil. Por meio dele, os comportamentos privados seriam afetados pela censura maior nos comportamentos e a prevenção e dissuasão de condutas lesivas iriam ser promovidas, contribuindo para a redução de danos e maior proteção para os indivíduos:

O princípio da punição na responsabilidade civil tem como conteúdo, dessa forma, o reconhecimento da atribuição de uma pena sempre adicional aos danos ocasionados, quer patrimoniais, quer extrapatrimoniais, em virtude, de um lado, do imperativo ético de censurar e apenar condutas negativas, delimitar responsabilidades e assim proceder à regulação dos privados, bem como, de outro lado, da necessidade de inibição de condutas idênticas, pelo mesmo ofensor ou pelos demais membros da sociedade. Reconhece o princípio, assim, função à responsabilidade civil que vai além do mero ressarcimento de danos, retrospectiva por um lado, mas prospectiva por outro. ${ }^{96}$

Não seria um retorno ao estágio do século XIX, com a responsabilidade eminentemente subjetiva, mas um passo evolutivo, como foi o surgimento da responsabilidade objetiva, com o intuito de conferir maior proteção para os direitos individuais e coletivos. Há uma função protetiva por meio de um meio flexibilizado que é a responsabilidade civil, diferentemente do Direito Penal e Direito Administrativo que lidam com pontos mais densos e relevantes, como a liberdade e a pena capital. ${ }^{97}$

O fundamento apontado por Cunha para a aplicação da punição compreende princípios éticos de responsabilidade e de justiça, em que se confere a cada um segundo os méritos e deméritos. O autor embasa com o "resgate dos valores éticos" no Código Civil,

96 CUNHA, Wladimir Alcibíades Marinho Falcão. Danos extrapatrimoniais e função punitiva. 2012. Tese (Doutorado) - Faculdade de Direito, Universidade de São Paulo, São Paulo. p. 137-138.

${ }_{97}$ CUNHA, Wladimir Alcibíades Marinho Falcão. op. cit., p. 138. A punição contribuiria para a regulação e segurança das relações jurídico-privadas, intensificando a confiança e a boa-fé, bem como contribuindo para a ordem econômica. Ressalta-se que o autor defende a aplicação dos punitive damages no direito brasileiro, efeito de uma adaptação às peculiaridades de nosso ordenamento. Para fundamentar a possibilidade de aplicação dos punitive damages no direito brasileiro, Cunha expõe argumentos e pontos de semelhanças entre a common law e o statute law, mostrando uma convergência entre ambos. O primeiro ponto é que se nota, na common law, a maior força do direito estatuído frente aos precedentes judiciais. Em sentido oposto, no statute law, observa-se maior importância da jurisprudência nas decisões, inclusive exercendo influências. A súmula vinculante faz parte dessa tendência. $\mathrm{O}$ autor fala que o tort law norte-americano possui uma grande aproximação com o instituto da responsabilidade civil do civil law, pela grande quantidade de material comum entre ambos e pelas soluções jurídicas para os casos concretos. O autor fala que não é pelas divisões existentes em ambos. Outro ponto de convergência compreende os juízes, em que nos dois sistemas jurídicos o juiz não estaria engessado em situações em que eles se deparam com novos danos. Por fim, o autor explica que o diálogo entre os sistemas faz parte da pós-modernidade, havendo uma troca de experiências e de entendimentos sobre aspectos jurídicos (Ibid., p. 139-143). 
por meio do princípio da eticidade. Ademais, ao defender o controle nos comportamentos privados e nas relações econômicas, observa-se que o princípio da socialidade também está presente na aplicação da punição na responsabilidade civil. ${ }^{98}$

O autor buscou bases teóricas no próprio Código Civil para a sustentação de sua tese a respeito da aplicação do princípio ético-jurídico da punição na seara do direito privado. Assim, a preocupação social emerge dessa discussão, principalmente no tocante à proteção a ser conferida às pessoas. Não é simplesmente pensar em punição por punição, mas, sim, procurar melhorar os comportamentos e a vida social por meio de um instrumento adaptado às novas exigências da sociedade.

Aqui se manifesta a ideia de não haver um retorno ao passado, mas, sim, uma visão preocupada com a prevenção dos danos já conhecidos pelo Direito. ${ }^{99}$ À primeira vista, pode parecer um saudosismo das origens da responsabilidade civil, mas, pelo contrário, nos parece um passo para a proteção maior dos direitos da personalidade, da dignidade humana, que merecem a proteção adequada e proporcional para variadas situações. Ademais, a confiança nas relações jurídicas pode ser fortalecida por meio da aplicação da punição. O maior respeito perante o outro, e a satisfação das expectativas individuais tendem a intensificar a segurança e consolidar comportamentos privados marcados pela cooperação e no respeito. ${ }^{100}$

Para ressaltar a crítica de que a indenização punitiva na responsabilidade civil deve vir prevista por lei, Bassan explica que o Direito Civil contém punições, mas elas estão presentes em dispositivos normativos. ${ }^{101}$ Evidencia-se, portanto, que a falta de uma previsão legislativa é o maior empecilho para a aplicação efetiva da indenização punitiva, pois há uma situação de insegurança com a aplicação de punição sem uma regulamentação, embora haja argumentos (como serão vistos) que se baseiam no texto constitucional e nos princípios do Código Civil.

Ademais, a autora afirma que a mera reparação dos danos morais já provoca um sentimento nas pessoas de que estão sendo punidas, estimulando a prevenção. Neste sentido, ela não vê a necessidade de aplicação da função punitiva. A reparação dos danos seria um meio capaz de provocar a prevenção, sem qualquer majoração do quantum arbitrado. Quanto ao magistrado, seu papel seria de levar em consideração prudentemente

98 CUNHA, Wladimir Alcibíades Marinho Falcão. Danos extrapatrimoniais e função punitiva. 2012. Tese (Doutorado) - Faculdade de Direito, Universidade de São Paulo, São Paulo. p. 143 e ss.

99 Neste sentido, BENACCHIO, Marcelo. A função punitiva na responsabilidade civil no Código Civil. In: LOTUFO, Renan; NANNI, Giovanni Ettore; MARTINS, Fernando Rodrigues (Org.). Temas relevantes do direito civil contemporâneo: reflexões sobre os 10 anos do Código Civil. São Paulo: Atlas, 2012. p. 647-648.

100 CUNHA, Wladimir Alcibíades Marinho Falcão. op. cit., p. 148.

101 BASSAN, Maria Alcazas. As funções da indenização por danos morais e a prevenção de danos futuros. 2009. Dissertação (Mestrado) - Faculdade de Direito, Universidade de São Paulo, São Paulo. p. 81. 
as circunstâncias do caso concreto, de modo que a reparação fosse a mais perfeita possível. ${ }^{102}$

Além de observarmos que a compensação não é associada ao comportamento do agente e, portanto, não causa desestímulo para a prática lesiva, notamos que se houvesse uma função preventiva exercida pela compensação ela seria ineficaz. Assim o é porque há vários danos morais sendo cometidos, seja na internet ou não.

Numa visão mais próxima dos valores e princípios constitucionais, $\mathrm{Melo}^{103}$ explica que a responsabilidade civil deve ser estudada e interpretada segundo os princípios constitucionais da solidariedade e da dignidade humana. Esta, como fundamento da República (Art. $1^{\circ}$, III, CF) aparece como valor a nortear o ramo do Direito Civil.

Voltado às atividades industriais e econômicas, a atenção do Direito e das pessoas não era relacionada aos próprios indivíduos, mas, sim, ao lucro. Diferentemente, a sociedade pós-moderna distingue-se porque a preocupação maior atualmente é a proteção do indivíduo, baseando-se em sua dignidade. ${ }^{104}$

$\mathrm{O}$ indivíduo era visto, até meados do século $\mathrm{XX}$, como um instrumento que provocava a criação de riquezas. Significa dizer que ele era visto como um instrumento para a economia, não tendo uma relevância maior que isto, que alcançasse um valor em sua dignidade. Qualquer dano que houvesse na esfera da pessoa era equiparado, numa analogia, ao defeito de uma máquina.

Com o passar do tempo e com a evolução dos entendimentos, a postura alterou-se e o indivíduo passou a ser visto com um valor inerente à sua condição de pessoa.

Aos poucos, o sujeito passa a ser compreendido não só pela sua capacidade de produzir riquezas, mas por diversos outros prismas, constatando-se que o bem-estar do sistema depende do bem-estar do próprio indivíduo. ${ }^{105}$

Levy ${ }^{106}$ explica que essa comparação entre o "bem-estar do indivíduo" e o "bem-estar do sistema" não se baseia numa preocupação com a dignidade, mas numa preocupação com o próprio sistema, visto que se preocupa com o bem-estar com o sistema primeiro para depois pensar no indivíduo. É como se pensasse que o indivíduo deve estar

102 BASSAN, Maria Alcazas. As funções da indenização por danos morais e a prevenção de danos futuros. Dissertação (Mestrado) - Faculdade de Direito, Universidade de São Paulo, São Paulo. p. 96-97 e p. 105 e SS.

103 MELO, Diogo Leonardo Machado de. Ainda sobre a função punitiva na reparação por danos morais (e a destinação de parte da indenização para entidades de fins sociais - art. 883, parágrafo único, do Código Civil). Revista de Direito Privado, São Paulo, v. 7, n. 26, p. 105-145. abr./jun. 2006. p. 111 e ss.

104 LEVY, Daniel de Andrade. Responsabilidade civil: de um direito dos danos a um direito das condutas lesivas. São Paulo: Atlas, 2012. p. 19.

105 Ibid., loc. cit.

106 Ibid., loc. cit. 
bem para ele trazer frutos para o próprio sistema. A partir da sociedade pós-moderna, o entendimento é alterado e o homem é visto a partir de sua dignidade e não pela sua capacidade de produzir, tanto que houve uma mudança no próprio texto do Código Civil de $2002 .^{107}$

Além da dignidade humana, a Constituição colocou como objetivo da República a construção de uma sociedade justa, livre e solidária e a erradicação da pobreza, pontos que também servirão para nortear a responsabilidade civil. A influência do princípio da solidariedade, da dignidade humana e dos outros valores constitucionais coloca a importância no ser e não no ter, isto é, a proteção da pessoa torna-se o principal objetivo a ser seguido, deixando de lado concepções patrimonialistas que seriam favorecidas.

Numa comparação, basta observar o retrospecto histórico da acolhida do dano moral no direito brasileiro. Devido às dificuldades intrínsecas ao dano moral, como a inexatidão da indenização, havia opiniões contrárias à recepção do dano moral como dano a ser reparado. Assim, muitas indenizações se prendiam a aspectos patrimoniais, como no caso de concessão de indenização por morte de filho menor, não pelo motivo de se perder um filho ou um membro da família, mas pelo fato de se perder uma oportunidade futura de uma ajuda no sustento da casa e da família. ${ }^{108}$

Dessa forma, a preocupação social está presente no direito privado, de modo que as relações privadas não podem ser levadas em conta em sua individualidade, somente levando em conta as partes, mas tem que levar em conta o aspecto social a qual o dano e o acontecimento ocorreram.

Ademais, a prevalência da dignidade humana, da solidariedade e do interesse coletivo acarreta uma reparação dos danos sobre os direitos da personalidade levando-se em conta não só os interesses individuais, mas, também, leva-se em conta "os direitos individuais sociais, que têm forte carga de solidariedade, seu pressuposto e fundamento". ${ }^{109}$

107 É importante comparar o exposto para perceber o entrave para o reconhecimento do dano moral no direito brasileiro. Se até meados do século XX o homem era importante enquanto produzia mercadorias, houve uma mudança deste entendimento no sentido de reconhecer o fato de que os indivíduos sofrem lesões a direitos da personalidade, principalmente em sua dignidade humana. Isso pode ser apontado como fator de influência na história do dano moral, assim como outras legislações que tiveram influência no Código Civil de 1916, como aponta Carmignani (CARMIGNANI, Maria Cristina. A evolução histórica do dano moral. Revista do Advogado, n. 49, dez. 1996. p. 39-40).

108 CAVALIERI FILHO, Sérgio. Programa de responsabilidade civil. São Paulo: Atlas, 2012. p. 110 e ss.

109 MELO, Diogo Leonardo Machado de. Ainda sobre a função punitiva na reparação por danos morais (e a destinação de parte da indenização para entidades de fins sociais - art. 883, parágrafo único, do Código Civil). Revista de Direito Privado, São Paulo, v. 7, n. 26. abr./jun. 2006. p. 112. 
São esses os principais canais de atuação do Direito na sociedade atual, que permitirão compreender as soluções propostas à procura de uma tutela mais justa e eficiente do indivíduo. A Responsabilidade Civil aparecerá, aqui, como o ramo que mais fielmente refletirá essa busca pela tutela do indivíduo à luz de uma perspectiva nitidamente coletiva. ${ }^{10}$

A adoção da indenização punitiva na responsabilidade civil torna-se implantar o reequilíbrio social ${ }^{111}$ após a ocorrência de um dano, no que concerne aos danos aos direitos da personalidade, mais precisamente, aos danos extrapatrimoniais.

A adoção da indenização punitiva no caso de danos morais não deve perder de vista a função compensatória dos danos, ou seja, a preocupação em reparar os danos sofridos pela vítima. A punição apareceria como instrumento para introduzir a prevenção dos danos e o efeito de desestímulo, baseando-se na importância de se defender a dignidade humana. ${ }^{112}$

Benacchio sustenta que o art. $5^{\circ}, \mathrm{V}$ e X, CF fundamenta a função punitiva da responsabilidade civil. Segundo ele, não somente a reparação dos danos está presente, mas também a função punitiva. ${ }^{113}$

A partir da observação de que o Direito deve se adequar à realidade social, não bastando o texto escrito, mas também a realidade vigente, o autor diz:

110 LEVY, Daniel de Andrade. Responsabilidade civil: de um direito dos danos a um direito das condutas lesivas. São Paulo: Atlas, 2012. p. 24.

111 Moraes defende a tese de que a prática de indenizações punitiva na responsabilidade civil não deve ser praticada porque há inúmeros problemas, como o enriquecimento sem causa da vítima que recebe a indenização e o fato de a função reparatória ser predominante na responsabilidade civil. Entretanto, a autora faz uma ressalva importante para o tema em questão. A jurista entende que se uma conduta ilícita for reiteradamente praticada, causando danos a terceiros, é necessário que haja uma resposta efetiva do ordenamento e uma aplicação de indenização punitiva na responsabilidade civil. Ela afirma isso com um tom de uma ressalva, como uma exceção à regra geral: "É de admitir-se, pois, como exceção, uma figura semelhante à do dano punitivo, em sua função de exemplaridade, quando for imperioso dar uma resposta à sociedade, isto é, à consciência social, tratando-se, por exemplo, de conduta particularmente ultrajante, ou insultuosa, em relação à consciência coletiva, ou, ainda, quando se der o caso, não incomum, de prática danosa reiterada. Requer-se a manifestação do legislador tanto para delinear as estremas do instituto, quanto para estabelecer as garantias processuais respectivas, necessárias sempre que se trate de juízo de punição. É de aceitar-se, ainda, um caráter punitivo na reparação de dano moral para situações potencialmente causadoras de lesões a um grande número de pessoas, como ocorre nos direitos difusos, tanto na relação de consumo quanto no Direito Ambiental. Aqui, a ratio será a função preventivo-precautória, que o caráter punitivo inegavelmente detém, em relação às dimensões do universo a ser protegido" (MORAES, Maria Celina Bodin de. Danos à pessoa humana: uma leitura civil-constitucional dos danos morais. Rio de Janeiro: Renovar, 2003. p. 263). No mesmo sentido, SCHBEIRER, Anderson. Arbitramento do dano moral no Novo Código Civil. Revista Trimestral de Direito Civil, Rio de Janeiro, v. 12, out./dez. 2002. p. 20-22.

112 MELO, Diogo Leonardo Machado de. op. cit., p. 126.

113 BENACCHIO, Marcelo. A função punitiva na responsabilidade civil no Código Civil. In: LOTUFO, Renan; NANNI, Giovanni Ettore; MARTINS, Fernando Rodrigues (Org.). Temas relevantes do direito civil contemporâneo: reflexões sobre os 10 anos do Código Civil. São Paulo: Atlas, 2012. p. 663. 
Nessa linha de pensamento, seria cabível interpretação da norma constitucional em sua valoração e efetividade por meio da qual a responsabilidade civil fosse limitada à função reparatória, indenitária? Não, a previsão constitucional deve estabelecer atuação da norma de responsabilidade civil em todas as situações, inclusive em sua função punitiva, do contrário, todas as punições civis presentes no Código Civil seriam inconstitucionais, pensamento indefensável. ${ }^{114}$

Analisando o art. 944, CC, Benacchio nota no parágrafo único do dispositivo a presença do princípio da punição na responsabilidade. Entende que apesar de o parágrafo único retirar a possibilidade de aumentar a indenização devido à sua redução de acordo com o grau de culpa, ele vê a culpa como elemento fundamental na análise da indenização, não envolvendo a extensão do dano. A partir disso, ele nota a presença de um princípio que permita a presença da função punitiva na responsabilidade civil. ${ }^{115}$

Apesar do art. 944, parágrafo único, do Código Civil não permitir a compreensão de uma cláusula geral da função punitiva em virtude da referência à limitação da indenização, é evidente a presença do princípio da relevância do grau de culpa que se prende à conduta culposa e não ao dano e, nessa perspectiva, pode ser utilizado como princípio para afirmação da presença da função punitiva da responsabilidade civil. ${ }^{116}$

Dessa forma, o art. 944, parágrafo único, associado ao art. 389, CC, cláusula geral da responsabilidade contratual, permite a importância do fator culpa na seara contratual e os arts. 186 e 944 estão associados ao art. $5^{\circ}$, V e X, CF, permitindo uma análise da culpa e sua importância para efetivas respostas do ordenamento a problemas sociais:

Os arts. 186 e 944 do Código Civil, em conformidade ao ditame constitucional incidente ( $\mathrm{CF}$, art. $5^{\circ}$, incs. V e X), tornam clara a relevância da culpa na responsabilidade civil, bem como resposta concreta às violações das normas de responsabilidade civil como meio de prevenção e restabelecimento do equilíbrio social. ${ }^{117}$

$\mathrm{O}$ argumento baseado no parágrafo único que coloca a culpa como critério para a redução do quantum indenizatório é utilizado como crítica, no sentido de que o momento em que a culpa é utilizada para alterar o quantum é no sentido de reduzi-lo,

\footnotetext{
114 BENACCHIO, Marcelo. op. cit., p. 665.

115 Ibid., p. 666.

116 Ibid., loc. cit.

117 Ibid., p. 667.
} 
e não o contrário. Pensamos que esse dispositivo mostra que a culpa permanece como ponto importante e pode, sim, ser utilizada como base para a intensificação do valor a ser arbitrado, porém, com as ressalvas já feitas no sentido de que a reparação e a punição devem ter destinos diversos.

A proteção dos direitos da personalidade consubstanciada pelos incisos $\mathrm{V}$ e $\mathrm{X}$ do art. $5^{\circ}$, CF deve ser ampla, sendo possível haver a utilização do instrumento punitivo, mas reputamos indispensável um controle legal das situações, do modo como deve ser feito, para coibir qualquer espécie de abuso.

No Código Civil Português, existe uma disposição semelhante ao que há no parágrafo único do art. 944, CC. Trata-se do art. 494:

Quando a responsabilidade se fundar na mera culpa, poderá a indemnização ser fixada, equitativamente, em montante inferior ao que corresponderia aos danos causados, desde que o grau de culpabilidade do agente, a situação económica deste e do lesado e as demais circunstâncias do caso o justifiquem.

Citada por Benacchio, Paula Meira Lourenço explica que a doutrina portuguesa entende que há uma função punitiva e preventiva neste dispositivo, que permite que a culpa seja considerada para aumentar ou reduzir o quantum:

Como bem se compreende, se a função da responsabilidade civil fosse meramente reintegrativa e não se destinasse a punir os actos contrários ao Direito, o grau de culpa do agente não teria qualquer relevância na determinação da indemnização. Como não é isso que acontece, como supra verificámos, a maioria da doutrina portuguesa defende que o artigo $494 .^{\circ}$ consubstancia uma manifestação da função sancionatória, repressiva ou punitiva e preventiva da responsabilidade civil, porque o quantum indemnizatório é apurado atendendo ao grau de culpa leve do agente, admitindo-se que a indenização seja inferior ao dano causado. ${ }^{118}$

Marinangelo sustenta a função punitiva com base na dignidade humana e na supremacia do texto constitucional. Segundo o autor, como há a defesa e proteção

\footnotetext{
118 LOURENÇO, Paula Meira. A punição na responsabilidade civil. Coimbra: Almedina, 2006. p. 252-253 apud BENACCHIO, Marcelo. op. cit., p. 667. No mesmo sentido, GUIMARÃES, Patrícia Carla Monteiro. Os danos punitivos e a função punitiva da responsabilidade civil. Direito e Justiça: Revista da Faculdade de Direito da Universidade Católica Portuguesa, v. 15, n. 1, p. 159-206, 2001. p. 162, nota de rodapé n. 7. A autora comenta que o fato de a culpa ser levada como critério para a responsabilidade civil faz com que haja uma certa função punitivo-preventiva. A autora comenta sobre a utilização da culpabilidade no direito português, no art. 494, do Código Civil Português (GUIMARÃES, Patrícia Carla Monteiro. op. cit., p. 165166).
} 
da dignidade humana no texto constitucional, ela já permite que haja a função punitiva com aplicada para a tutela da dignidade humana. Uma ressalva feita pelo autor é de que seria adequado haver uma regulamentação por parte do Código Civil para que não haja discussões a respeito. Ademais, os princípios da eticidade, socialidade e operabilidade do Código Civil permitem essa interpretação. ${ }^{119}$

A diversidade de posicionamentos sobre o tema torna um pouco confusa a abordagem e o consenso sobre o fundamento jurídico a respeito da função punitiva. Com efeito, a abstração torna-se muito presente nas discussões, prejudicando o desenvolvimento da teoria. Schreiber e Tepedino, críticos da função punitiva, afirmam que há várias normas que remetem à entrega de uma quantia além daquela que deveria ser ressarcida, mas há uma dificuldade de reunir todos esses posicionamentos num ponto em comum e não muito abstrato. $^{120}$

Com base no exposto, vê-se que a indenização punitiva aparece defendida sobre diversos ângulos, seja na aproximação existente entre o Direito Penal e o Direito Civil, seja na importância de se garantir uma proteção intensa e eficaz sobre os valores constitucionais da dignidade humana e da solidariedade, ou mesmo na sustentação da elevação da responsabilidade civil ao lado da ineficácia do Direito Administrativo e das burocracias que marcam a responsabilidade penal e como um princípio interpretativo a ser imposto no controle dos comportamentos privados.

Há uma convergência destes argumentos no sentido de se aplicar a indenização punitiva com o intuito de prevenção primordialmente e não apenas com o objetivo de punição. Assim, a indenização torna-se punitivo-preventiva, procurando reparar os danos e, ao mesmo tempo, desestimular sua prática. ${ }^{121}$

Argumenta-se que a aplicação da pena privada na responsabilidade civil seria um retrocesso a um estágio que o Direito já ultrapassou com sua evolução. A existência da vingança privada e da punição no direito romano já teria sido afastada

119 MARINANGELO, Rafael. A evolução da indenização por dano moral e a aplicação da indenização punitiva. In: LOTUFO, Renan; NANNI, Giovanni Ettore; MARTINS, Fernando Rodrigues (Org.). Temas relevantes do direito civil contemporâneo: reflexões sobre os 10 anos do Código Civil. São Paulo: Atlas, 2012. p. 697698.

120 SCHREIBER, Anderson; TEPEDINO, Gustavo. As penas privadas no direito brasileiro. In SARMENTO, Daniel; GALDINO, Flavio. Direitos fundamentais: estudos em homenagem Ricardo Lobo Torres. Renovar: Rio de Janeiro, 2006. p. 506.

121 "Punição e prevenção, quer nos parecer, podem ser tomados conjugadamente, pois, ao punir-se, também previne-se, mas sempre poderão ser analisados separadamente, como funções exercidas pela responsabilidade civil como um todo, não apenas da reparação por danos morais, e mesmo como princípios que claramente emergem dos diversos câmbios da disciplina" (CUNHA, Wladimir Alcibíades Marinho Falcão. Danos extrapatrimoniais e função punitiva. Tese (Doutorado) - Faculdade de Direito, Universidade de São Paulo, São Paulo. p. 125-126). 
com a construção moderna da responsabilidade civil pelos franceses, sem a existência da indenização punitiva.

Como a responsabilidade civil vem se preocupando com a vítima gradativamente ao longo de sua evolução, a indenização punitiva insere-se neste retrospecto protetivo. Das dificuldades de se provar a culpa surgiu a responsabilidade objetiva. Posteriormente, a evolução da responsabilidade civil culminou na coletivização e no surgimento dos seguros e do aumento do rol de danos tuteláveis, proporcionando maior facilidade de indenizações. ${ }^{122}$

Como um aprimoramento da proteção, a punição amplia a proteção dada à vítima porque almeja a prevenção dos danos. Muito mais importante que a própria reparação de certos danos, que podem ser até irreparáveis por inteiro, a indenização punitivo-preventiva almeja uma situação em que haja uma redução dos danos. Isso se torna mais visível quando os danos são graves, como os danos morais na internet.

A dignidade da pessoa humana orienta essa preocupação social com a prevenção dos danos. Nossa visão é de que o histórico da responsabilidade civil demonstra essa proteção gradativa que foi se projetando, até chegar à prevenção dos danos. Numa evolução, a punição passa a atuar também nessa proteção da pessoa humana e a função punitivo-preventiva é introduzida na responsabilidade civil.

Sustentar a inviabilidade da indenização punitiva por não haver um dispositivo normativo que a permita é plausível, porém, é equivocada a tentativa de afastamento da indenização punitiva com a fundamentação na importância dada à reparação.

Por fim, faz-se necessário estudar as críticas incidentes sobre a indenização punitiva e, ao mesmo tempo, fornecer respostas a elas, tentando refutá-las.

\subsubsection{A separação entre a pena e a indenização}

No direito antigo, não havia distinção entre pena e indenização, mas existia a ideia de vingança sobre o agente que praticou o dano.

A responsabilidade civil inicialmente era voltada para o corpo do agente, "infligida ao corpo do ofensor, ligada a todo o grupo em que se inseria o indivíduo

122 Guimarães aponta que a reparação tende a ser indiferente com a realização dos danos. Não haveria uma contribuição ou estímulo para proteger mais intensamente os direitos alheios. A consequência seria um menor incentivo para que as pessoas se preocupem com seus próprios bens (GUIMARÃES, Patrícia Carla Monteiro Guimarães. Os danos punitivos e a função punitiva da responsabilidade civil. Direito e Justiça: Revista da Faculdade de Direito da Universidade Católica Portuguesa, v. 15, n. 1, p. 159-206, 2001. p. 178). 
vilipendiado em sua integridade ou em seus bens, bem ainda desproporcional". Não havia qualquer participação e influência do Estado. ${ }^{123}$

A pena de talião trouxe uma reciprocidade entre o dano e a pena, ainda que fosse corporal. Antes dela, já era possível remir a pena corporal com uma pena pecuniária. Essa remição ocorreu em dois momentos sucessivos. Num primeiro momento, a aceitação da quantia pecuniária ocorria por meio de negociação privada. Num segundo, o Estado e os grupos sociais começaram a fornecer diretrizes e regulamentações, colocando determinada cifra em dinheiro. ${ }^{124}$

$\mathrm{O}$ direito romano era caracterizado pela existência de uma pena que exercia a dupla função de reparação e de punição do agente, de modo que seu quantum era calculado a partir da multiplicação do valor do dano. Naquele direito, distinguia-se entre a pena e a indenização. ${ }^{125}$

Um exemplo é o crime de furto que previa penas privadas relacionadas à gravidade do delito. A partir do período pré-clássico e clássico, separaram-se os delitos privados e os delitos públicos, com existência somente nestes da pena privada.

Não eram todas as condutas que vinham acompanhadas de uma poena, mas somente delitos típicos. Cabia a uma iniciativa privada para ter a quantia paga. Posteriormente, o Estado Romano tomou para si o cuidado apenas daquelas condutas mais graves, denominadas crimina.

O escopo punitivo aparece nessas graduações que havia na quantia a ser paga. A reparação e a punição apareciam mescladas no montante pago pelo ofensor. ${ }^{126}$

Guimarães explica que o fato de o indivíduo receber um montante superior ao dano efetivamente ocorrido era visto como algo ruim pela doutrina canonista e por influência desta houve sua retirada. A culpa apenas apareceu na responsabilidade civil com a Lex Aquilia. ${ }^{127}$ Ela era aplicada nos casos de danos que aconteciam sobre escravos e

123 CUNHA, Wladimir Alcibíades Marinho Falcão. Danos extrapatrimoniais e função punitiva. 1944. Tese (Doutorado) - Faculdade de Direito, Universidade de São Paulo, São Paulo. p. 17 e DIAS, José de Aguiar. Da responsabilidade civil. Rio de Janeiro: Forense, 1944. v. 1, p. 22.

124 "É dizer, nem todos os atos danosos entre particulares geravam compulsoriedade no pagamento da poena, mas somente atos ou delitos tipificados denominados de delicta, e que, em conjunto, compunham o delictum, próprio do Ius Civile" (CUNHA, Wladimir Alcibíades Marinho Falcão. op. cit., p. 17-18).

125 LEVY, Daniel de Andrade. Responsabilidade civil: de um direito dos danos a um direito das condutas lesivas. São Paulo: Atlas, 2012, p. 37.

126 CUNHA, Wladimir Alcibíades Marinho Falcão. op. cit., p. 17 e DIAS, José de Aguiar. Da responsabilidade civil. Rio de Janeiro: Forense, 1944. v. 1, p. 19.

127 GUIMARÃES, Patrícia Carla Monteiro. Os danos punitivos e a função punitiva da responsabilidade civil. Direito e Justiça: Revista da Faculdade de Direito da Universidade Católica Portuguesa, v. 15, n. 1, p. 159206, 2001. p. 162 na nota de rodapé n. 12. 
animais. A culpa teve uma influência da filosofia grega e do pensamento cristão, não sendo passível de tipificação de condutas para a sua incidência. ${ }^{128}$

Cunha explica que a existência de ações meramente reparatórias (actiones rem tantum), da formação do critério da culpa e de ações mistas provocaram o distanciamento entre a responsabilidade civil e a responsabilidade penal. Assim, a primeira seria restrita à reparação dos danos:

Com o aprofundamento da noção de culpa, ao que se somava a existência em Roma também unicamente ressarcitórias (aciontes rem tantum), ou pelo menos ações mistas, o fosso entre as espécimes de sanções públicas e privadas somente se aprofundou dali em diante, dentro de um processo paulatino de separação entre as responsabilidades civis e penais e de firmamento da ideia de que a indenização civil deveria circunscrever-se ao ressarcimento do dano apenas. A pena privada romana, concedida em montante maior do que os danos efetivos, começava a ceder. ${ }^{129}$

Além disso, a separação entre os delitos privados e os delitos públicos ${ }^{130}$ foi consequência também do crescimento do Império Romano que passou a tomar para si a tarefa de punir os agentes que praticassem danos.

A crescente intervenção estatal começa a marcar os casos de delitos que também violariam direitos da coletividade e que, por tal razão, justificam a presença de um servidor do Império para conhecer a questão. O Direito dos Delitos, antes totalmente privado, passa a deslocar parte de sua matéria para o controle do Estado, com uma distinção cada vez mais nítida entre procedimento civil e procedimento penal. $\mathrm{O}$ juiz criminal, inclusive, passou a ser competente para atribuir à vítima uma compensação e destinar ao Estado a pena pecuniária. ${ }^{131}$

Além deste fator, a distinção entre a sanção civil e a penal derivou da necessidade de homogeneizar as regras da responsabilidade civil e para promover a restrição da indenização ao valor da perda patrimonial. ${ }^{132}$

128 CUNHA, Wladimir Alcibíades Marinho Falcão. op. cit., p. 20.

129 Ibid., p. 19.

130 "Quando assumiu a direção da composição dos pleitos, a autoridade começou também a punir, substituindose ao particular na atribuição de ferir o causador do dano. Evoluiu, assim, da justiça punitiva exclusiva, reservada aos ataques dirigidos diretamente contra ela, para a justiça distributiva, percebendo que, indiretamente, era também atingida por certas lesões irrogadas ao particular, porque perturbavam a ordem que se empenhava em manter. Resultou daí a cisão dos delitos em duas categorias: os delitos públicos (ofensas mais graves, de caráter perturbador da ordem) e os delitos privados. Aqueles eram reprimidos pela autoridade, como sujeito passivo atingido; nos últimos, intervinha apenas para fixar a composição evitando os conflitos" (DIAS, José de Aguiar. op. cit., p. 23).

131 LEVY, Daniel de Andrade. op. cit., p. 39.

132 COSTA, Judith Martins; PARGENDLER, Mariana Souza. Usos e abusos da função punitiva. Revista CEJ/ 
As ações penais passaram a integrar um Direito Criminal. O delito ficou na esfera privada com direito à indenização enquanto o crime, sob a punição estatal.

Mesmo nos casos dos delitos privados que conservaram um cunho punitivo, passou-se a distinguir aquilo que era compensatório daquilo que era punitivo, como no caso da pena do triplo, em que o simplum era concedido a título de compensação e, o resto, a título de punição. ${ }^{133}$

No direito dos bárbaros houve a permanência da função punitiva no Direito Privado, de modo que isso repercutiu no direito anglo-saxão, que admitem os punitive damages. Houve no direito português uma influência do direito bárbaro, mas o direito romano foi traduzido e logo houve a prevalência da aplicação do Direito Romano. No Brasil, as Ordenações Filipinas regravam a vida aqui e, embora tivessem normas de morte do carcereiro que deixasse algum preso escapar, havia uma divisão do regramento penal e civil. ${ }^{134}$

A pena privada defendida modernamente separa-se da pena aplicada no Direito Romano. Neste, a punição estava centrada num rol tipificado de condutas, os delitos privados, que hoje seriam os delitos públicos. Enquanto isso, a pena privada moderna está presente na atividade jurisdicional do juiz, não se prendendo à tipificação prévia:

[...] o que se ressalta essencialmente é o desempenho de uma função punitiva da responsabilidade civil como um todo, já que dentro de um paradigma da responsabilidade civil não mais tipificada, se não legislativamente, ao menos jurisprudencialmente, isto é, eleva-se a articulação punitiva da responsabilidade civil num lócus amplo de conformação social e de regulação da atividade econômica privada. ${ }^{135}$

Conselho da Justiça Federal, Brasília: CEJ, v. 9, n. 28, jan/mar. 2005. p. 17 e ss. Levy explica que a divisão entre responsabilidade civil e responsabilidade penal deu-se por motivos políticos, com a separação do Direito Público e do Direito Privado (LEVY, Daniel de Andrade. Responsabilidade civil: de um direito dos danos a um direito das condutas lesivas. São Paulo: Atlas, 2012. p. 42).

133 LEVY, Daniel de Andrade. Responsabilidade civil: de um direito dos danos a um direito das condutas lesivas. São Paulo: Atlas, 2012. p. 39.

134 Ibid., p. 40.

135 CUNHA, Wladimir Alcibíades Marinho Falcão. Danos extrapatrimoniais e função punitiva. Tese (Doutorado) - Faculdade de Direito, Universidade de São Paulo, São Paulo. p. 64. 
1.2.3. Críticas sobre a aplicação da indenização punitiva.

a) Indenizações exageradas

A crítica incide sobre o fato de que a indenização punitiva pode provocar a ocorrência de quantum indenizatório de valores elevados e desproporcionais, provocando situações ruins para o direito e para a justiça. ${ }^{136}$

Andrade refuta este argumento explicando que o direito brasileiro não prevê a ocorrência de júris populares para o arbitramento de danos morais, como o faz no Common Law. ${ }^{137}$ Ademais, o direito brasileiro prevê a possibilidade de revisão dos valores das indenizações, o que seria uma maneira de evitar a ocorrência de pesadas indenizações. A possibilidade de indenizações desproporcionais está presente também no arbitramento dos lucros cessantes, portanto, não é algo inerente à indenização punitiva nem algo que seja óbice para sua aplicação. ${ }^{138}$

Realizando a separação da reparação dos danos e a punição pelo comportamento em dois montantes distintos, talvez não haja esse problema porque a possibilidade de controle seria maior e, associado a isto, deveria haver uma fundamentação extensa e abrangente do juiz, considerando todas as circunstâncias do caso concreto. Assim, seria mais difícil haver um quantum desproporcional após a verificação de todos os casos concretos e de uma fundamentação adequada pelo juiz.

b) Enriquecimento sem causa da vítima

Uma das principais críticas incidentes sobre a indenização punitiva é o fato de haver enriquecimento sem causa com a transferência do quantum majorado para a vítima. ${ }^{139}$

136 SCHBEIRER, Anderson. Arbitramento do dano moral no Novo Código Civil. Revista Trimestral de Direito Civil, Rio de Janeiro, v. 12, out./dez. 2002. p. 14. Após argumentar que a aplicação da função punitiva iria de encontro à tradição romano-germânica, o autor questiona o porquê de não haver indenização punitiva nos danos patrimoniais. Uma tentativa de resposta é que a indenização punitiva não deve ser aplicada em todos os casos de danos extrapatrimoniais, mas, sobretudo naquelas situações graves como vemos no dano moral na internet. Outra crítica do autor é de que a função punitiva iria de encontro com a responsabilidade objetiva, que não leva em conta a culpa do agente. Ademais, ele comenta que os seguros de responsabilidade civil podem retirar a eficácia preventiva da função punitiva (Ibid., loc. cit.). Contrariamente ao que o autor sustenta, observa-se que a culpa vem se fortalecendo na responsabilidade civil com a ascensão dos princípios da prevenção e da precaução. Dessa forma, a responsabilidade subjetiva seria reforçada.

137 ANDRADE, André Gustavo Corrêa. Dano moral e indenização punitiva. 2. ed. rev. atual. Rio de Janeiro: Lumen Juris, 2009. p. 272. Lopez comenta a respeito da prática comum dos advogados do common law em que advogados procuram ajuizar demandas em locais onde a probabilidade de se ter uma indenização elevada é grande. Trata-se da prática do forum shopping (LOPEZ, Teresa Ancona. Princípio da precaução e evolução da responsabilidade civil. São Paulo: Quartier Latin, 2010. p. 82).

138 ANDRADE, André Gustavo Corrêa. op. cit., p. 272.

139 PIZARRO, Ramón Daniel. Daño moral. Prevención. Reparación. Punición. El daño moral en las diversas 
Antonio Junqueira de Azevedo trata do dano social. Os danos sociais geram uma repercussão na vida da sociedade, de modo que a tranquilidade deve retornar àquela. Segundo ele, é possível a indenização punitiva a título de dano social, ao lado de indenização para a vítima diretamente. Há uma preocupação com o dano que atinge a sociedade como um todo. ${ }^{140}$

O autor sustenta a aplicação da indenização punitiva como forma de prevenção e dissuasão do cometimento desses danos. A respeito da destinação da indenização, Junqueira alega que a vítima teve um esforço despendido para ajuizar a ação, de modo que seria um retorno àquilo que ela fez. Quanto à possibilidade de envio a um fundo, o autor diz que seria para a sociedade, mas haveria um encargo para o Estado, que está cheio de trabalho. Para o autor, ele exerce um munus público de modo que ele age para o bem da sociedade e, portanto, ele pode receber uma contraprestação por sua recompensa. ${ }^{141}$

A primeira crítica é que não se pode incentivar uma conduta social para o bem da coletividade utilizando uma contrapartida pecuniária. $\mathrm{O}$ entendimento do autor é coerente, porém, não consideramos que seja necessário o envio do acréscimo para a própria vítima. Além disso, deve-se atentar-se para a necessidade de as pessoas realizarem o bem para a sociedade sem a necessidade de uma contrapartida financeira.

Schreiber e Tepedino argumentam que os problemas que suscitam a função punitiva advêm do próprio comportamento individual e, contrariando essa situação, o dinheiro oriundo da punição seria transmitido para o corpo coletivo, onde os danos surgem. ${ }^{142}$ Há coerência neste pensamento e, também, deve-se pensar que a punição tem uma preocupação social, não individual com a vítima. O objetivo de prevenir não é somente com a pessoa que sofre o dano, mas principalmente com o corpo coletivo que também é afetado pelos danos.

Por sua vez, Andrade sustenta que a indenização punitiva deve ser entregue para a vítima do dano moral, explicando que a própria decisão do juiz é a causa para o enriquecimento da pessoa que sofreu o dano. Dessa forma, não haveria enriquecimento sem causa. ${ }^{143}$

ramas del Derecho. Hammurabi, 2000, p. 88.

140 AZEVEDO, Antonio Junqueira de. Por uma nova categoria de dano: o dano social. In: Novos estudos e pareceres de direito privado. São Paulo: Saraiva, 2009. p. 381.

141 "Embora esse ponto não seja facilmente aceito no quadro da mentalidade jurídica brasileiro, parece-nos que é preciso recompensar, e estimular, aquele que, embora por interesse próprio, age em benefício da sociedade. Trata-se de incentivo para um aperfeiçoamento geral" (Ibid., p. 382-383).

142 SCHREIBER, Anderson; TEPEDINO, Gustavo. As penas privadas no direito brasileiro. In: SARMENTO, Daniel; GALDINO, Flavio. Direitos fundamentais: estudos em homenagem Ricardo Lobo Torres. Renovar: Rio de Janeiro, 2006. p. 524.

143 ANDRADE, André Gustavo Corrêa. Dano moral e indenização punitiva. 2. ed. rev. e atual. Rio de Janeiro: 
Além disso, o autor diz que nos casos de violação da dignidade da pessoa humana, não há que se falar de enriquecimento sem causa ${ }^{144}$ e entende que é plenamente viável e lícito que a vítima tenha um enriquecimento com a indenização punitiva.

Particularmente, entendemos que nos casos em que a função punitiva da indenização deve ser aplicada, deve haver uma separação dos valores da reparação, de modo que uma porção constitua o quantum destinado à compensação dos danos e outra parte paga pelo autor do dano seja constituída a título de punição.

Pensamos que a existência de um ganho patrimonial da vítima caracteriza o enriquecimento sem causa, portanto, a porção paga pelo autor do dano a título de punição deve ser entregue a uma entidade social, de modo que a vítima não aufira um lucro com o dano que sofreu.

O beneficiário da punição e da prevenção decorrente daquela é a vítima e a sociedade, mas esta principalmente. Além de a punição ser desvinculada da reparação, ela deve ser destinada para a própria sociedade, pois o intuito primordial é social.

Melo defende este entendimento argumentando que o objetivo de haver a indenização punitiva é em benefício do interesse social, portanto, o destino da indenização punitiva deve ser justamente a coletividade, por meio de uma entidade social que possa promover auxílio para a sociedade com o dinheiro remunerado das indenizações. ${ }^{145}$

Este argumento baseia-se no art. 883, CC e também na Lei de Ação Civil Pública (Lei n. 7347/85). ${ }^{146}$

Levy faz um breve estudo sociológico das sociedades dos países da Common Law e dos países de sistema jurídico romano-germânico. A predominância da religião protestante, nos primeiros, favoreceu o entendimento de que o enriquecimento

Lumen Juris, 2009. p. 275 e ss.

144 No mesmo sentido, MARINANGELO, Rafael. A evolução da indenização por dano moral e a aplicação da indenização punitiva. In: LOTUFO, Renan; NANNI, Giovanni Ettore; MARTINS, Fernando Rodrigues (Org.). Temas relevantes do direito civil contemporâneo: reflexões sobre os 10 anos do Código Civil. São Paulo: Atlas, 2012. p. 695. Com o mesmo entendimento praticamente, Benacchio argumenta que, nos casos de lucro ilícito, houve um benefício do autor em troca de violação do direito da vítima, portanto, o montante deve ser destinado à vítima: "A pena privada, enquanto modalidade da atuação da função punitiva da responsabilidade civil encerra possibilidade do pagamento à vítima de quantia em dinheiro que não tem liame com o dano e sim com o grau de reprovação da conduta culposa do responsável destinada à punição civil’. (BENACCHIO, Marcelo. A função punitiva na responsabilidade civil no Código Civil. In: LOTUFO, Renan; NANNI, Giovanni Ettore; MARTINS, Fernando Rodrigues (Org.). Temas relevantes do direito civil contemporâneo: reflexões sobre os 10 anos do Código Civil. São Paulo: Atlas, 2012. p. 657), dentre outros.

145 MELO, Diogo Leonardo Machado de. Ainda sobre a função punitiva na reparação por danos morais (e a destinação de parte da indenização para entidades de fins sociais - art. 883, parágrafo único, do Código Civil). Revista de Direito Privado, São Paulo, v. 7, n. 26. p. 105-145. abr./jun. 2006. p. 135-136.

146 Art. 13, da Lei n. 7347/1985: "Havendo condenação em dinheiro, a indenização pelo dano causado reverterá a um fundo gerido por um Conselho federal ou por Conselhos estaduais de que participarão necessariamente os Ministérios Públicos e representantes da comunidade, sendo seus recursos destinados à reconstituição dos bens lesados". 
dos indivíduos é um sinal positivo, no sentido de que as pessoas são recompensadas por suas atitudes. Os protestantes não questionam se receber uma quantia em dinheiro de indenização punitiva é um pecado ou algo ruim. Ademais, eles não colocam para si um papel importante para a salvação, de modo que não colocam culpa neles mesmos em relação ao futuro e aos seus atos, se "abandonando mais naturalmente à fatalidade da vida". ${ }^{147}$

Diferentemente dos protestantes, os católicos acreditam na ideia do livrearbítrio, de modo que a salvação está vinculada com o comportamento deles na vida terrena. Dessa forma, suas condutas são julgadas moralmente e o enriquecimento é visto como algo negativo.

$\mathrm{O}$ autor explica que isso se espraiou para a ordem jurídica e, na Common Law, não há um óbice moral para a entrega do quantum punitivo. Diferentemente, nos países de sistema jurídico romano-germânico, em que há o enriquecimento sem causa que veda essa transferência monetária do montante de função punitiva para o autor da ação. ${ }^{148}$

Tal como Junqueira no dano social, Levy entende que deve haver uma parcela do quantum punitivo para o indivíduo de modo que haja um incentivo para a ajuizamento da ação e, também, para evitar um empobrecimento delas. Não haveria problema em destinar parcela para fundo público, ${ }^{149}$ porém, seu posicionamento é de que é necessário partilhar entre o fundo e aquele indivíduo que ajuizou a ação perante o Poder Judiciário. ${ }^{150}$

Levy compara a sociedade norte-americana e a brasileira, e explica que a primeira foi formada por colonos que queriam construir uma nova vida aqui na América, construindo uma sociedade unida que se voltou para a proteção do indivíduo. A sociedade brasileira está vinculada com colonos que tinham o interesse de explorar economicamente a nova colônia, o que demonstra a diferença de intuitos na formação de ambas as sociedades. Além disto, os sistemas jurídicos apresentam características diversas em sua origem, de modo que o sistema romano-germânico está mais restrito a um rigorismo metodológico, como a divisão entre Direito Público e Direito Privado, que não está muito presente na Common Law. ${ }^{151}$

\footnotetext{
147 LEVY, Daniel de Andrade. Responsabilidade civil: de um direito dos danos a um direito das condutas lesivas. São Paulo: Atlas, 2012. p. 94.

148 Ibid., 95-96.

149 Na Europa, os fundos públicos existentes não possuem vinculação com a discussão em torno da função punitiva, tendo outros motivos alheios ao enriquecimento sem causa (Ibid., p. 50, nota de rodapé n. 86).

150 LEVY, Daniel de Andrade. Responsabilidade civil: de um direito dos danos a um direito das condutas lesivas. São Paulo: Atlas, 2012. p. 96-97.

151 Ibid., p. 98-103.
} 
c) Indústria do dano moral

Andrade ${ }^{152}$ argumenta que é inerente à democracia a prática de demandas com ou sem fundamento. É possibilitado o acesso à justiça a todos e isso faz parte. A partir disso, são necessários caminhos que possam oferecer demandas e indenizações justas. Deve haver uma "jurisprudência firme" que tire demandas sem fundamento. Ademais, há a questão da litigância de má-fé, no art. 18 CPC.

O que não é razoável é que se pretenda criar dificuldades de acesso ao Judiciário ou excluir importante instrumento de defesa da cidadania, como a indenização punitiva, a pretexto de desestimular as demandas temerárias. Se o preço a pagar pela efetividade ou concretização dos princípios constitucionais, em especial o da dignidade da pessoa humana, é possibilitar a propositura de ações temerárias e infundadas, então será um preço baixo a ser pago. ${ }^{153}$

Serpa afirma que o enriquecimento ilícito possível e querido pelos supostos ofendidos não é consequência da aplicação da função punitiva, mas de dois efeitos. $\mathrm{O}$ primeiro é de que as supostas vítimas abusam do direito processual e se fazem possíveis vítimas para ensejarem indenizações com o intuito de enriquecerem. Ademais, é resultado também de um abuso dos próprios Tribunais que erram no arbitramento da indenização e, por consequência, transmitem, segundo o autor, a ideia de que a tutela da dignidade humana também pode ser instrumento para "locupletamento ilícito". ${ }^{154}$

Neste sentido, propõe duas ordens de medidas para evitar a ocorrência de erros judiciais na aplicação das indenizações punitivas. Uma é a reiterada possibilidade de revisão do quantum indenizatório para que não haja nenhuma condenação a um valor altíssimo, gerando dano ao próprio indivíduo que deverá arcar com a indenização. A outra medida é o não provimento para pedidos de indenização sem nenhum fundamento jurídico, ou seja, não permitir que haja qualquer espécie de indenização com a mera alegação de dano moral. ${ }^{155}$ Concordamos porque é algo delicado na aplicação da função punitiva, ou seja, trata-se da mensuração da punição do agente que também deverá arcar com a reparação do dano.

\footnotetext{
152 ANDRADE, André Gustavo Corrêa. Dano moral e indenização punitiva. 2. ed. rev. e atual. Rio de Janeiro: Lumen Juris, 2009. p. 277.

153 Ibid., p. 278. No mesmo sentido, MARINANGELO, Rafael. A evolução da indenização por dano moral e a aplicação da indenização punitiva. In: LOTUFO, Renan; NANNI, Giovanni Ettore; MARTINS, Fernando Rodrigues (Org.). Temas relevantes do direito civil contemporâneo: reflexões sobre os 10 anos do Código Civil. São Paulo: Atlas, 2012. p. 696.

154 SERPA, Pedro Ricardo e. Indenização punitiva. 2011. Dissertação (Mestrado) - Faculdade de Direito, Universidade de São Paulo, São Paulo. p. 200.

155 Ibid., p. 201.
} 
Serpa considera as reformas recentes adotadas por alguns estados norteamericanos e faz a conclusão de que não haveria enriquecimento sem causa com a separação dos montantes reparatório e punitivo, tal como pensamos: ${ }^{156}$

Com efeito, ao se analisar as propostas apresentadas pelo tort reform movement para a utilização mais eficiente dos punitive damages, viu-se que uma das medidas já adotadas por determinados Estados norte-americanos é aquela que impõe a remessa parcial ou total da indenização punitiva a um fundo público, impedindo que o valor integral seja recebido pelo ofendido como "windfall payment". Desse fato, conclui-se não ser verídica a afirmação de que a destinação das quantias ao ofendido é elemento indissociável da indenização punitiva: por uma questão de política legislativa, a condenação imposta ao ofensor pode ser revertida integralmente à vítima, integralmente a um fundo público ou repartida entre a vítima e o fundo público. ${ }^{157}$

Percebe-se que ele sustenta possibilidade de uma política legislativa poder ser aplicada no sentido de dividir a quantia de modo que o causador do dano pagará a título de punição não irá para o bolso da vítima. Assim, Serpa afirma que a divisão da indenização em duas partes, de modo que a vítima possa receber uma parte e a outra seja destinada a um fundo público.

Trata-se de uma alternativa que deve ser seguida pelos países tendentes a utilizarem a indenização punitiva. As consequências são benéficas em vários sentidos. Primeiro porque a vítima não afere nenhuma espécie de lucro e, portanto, não haveria a crítica comumente apontada de que a indenização punitiva ensejaria o enriquecimento sem causa da vítima. Ademais, o escopo preventivo é esboçado nessa prática porque o indivíduo deve pagar duas espécies de indenização, uma compensatória para a vítima e outra punitiva que será transferida a um fundo público.

Assim, vê-se que o paradigma ressarcitório da responsabilidade civil é alterado, embora não deixe de existir. Ele passa a permitir a existência de indenizações punitivas de modo que se exerça a função preventiva.

156 Vaz compartilha do mesmo entendimento de que a transferência para um fundo público seria importante para impedir o enriquecimento sem causa. A autora explica que isso ocorre nos montantes derivados de ações civis públicas em ilícitos ao meio ambiente, contra o consumidor, a criança e o adolescente, dentre outros interesses coletivos (VAZ, Caroline. Funções da responsabilidade civil: da reparação à punição e dissuasão: os punitive damages no Direito Comparado e Brasileiro. Porto Alegre: Livraria do Advogado, 2009. p. 84-85).

157 SERPA, Pedro Ricardo e. Indenização punitiva. Dissertação (Mestrado) - Faculdade de Direito, Universidade de São Paulo, 2011. p. 202. 
d) Influência no exercício de atividades econômicas

Segundo a crítica, a indenização punitiva iria desencorajar as atividades econômicas. Há uma coerência, mas esta crítica não pode afastar um instituto jurídico nem há consistência que justifique essa redução econômica e temor com a indenização punitiva. ${ }^{158}$

e) O princípio da legalidade

A principal crítica que há sobre a indenização punitiva no caso dos danos morais é a alegação de que não há no ordenamento jurídico nenhuma previsão normativa permitindo a aplicação da punição por meio da responsabilidade civil, por meio da majoração do quantum indenizatório. ${ }^{159}$

Ressaltamos que o fato de que essa crítica encontra paralelo com as discussões sobre o art. 944, parágrafo único, CC que, para alguns, permite a utilização da culpa para majorar o quantum com intuito punitivo. Se realmente ele contempla a função punitiva, não haveria mais motivos para se argumentar a violação ao princípio da legalidade porque ele permitiria a utilização do critério da culpa e a majoração do quantum além da mera extensão do dano. Ao afirmar que há violação da legalidade, indiretamente, diz-se que o art. 944, parágrafo único, CC ou o próprio Código Civil (até mesmo o texto constitucional) não possui nenhum permissivo legal para a função punitiva.

Moraes ${ }^{160}$ compartilha deste pensamento argumentando que o Direito brasileiro recusou a aplicação dos punitives damages em vários momentos, como na vedação da aplicação da indenização punitiva no Código de Defesa do Consumidor. O dispositivo vetado determinava que:

[...] se comprovada a alta periculosidade do produto ou serviço que provocou o dano, ou grave imprudência, negligência ou imperícia do fornecedor, será devida multa civil de até um milhão de vezes o Bônus do Tesouro nacional - BTN, ou índice equivalente que venha substituílo, na ação proposta por qualquer dos legitimados à defesa

158 ANDRADE, André Gustavo Corrêa. Dano moral e indenização punitiva. 2. ed. rev. e atual. Rio de Janeiro: Lumen Juris, 2009. p. 279-280. Donnini entende que existe uma grande ocorrência de danos no cotidiano, criticando a ideia de que há indústria das indenizações (DONNINI, Rogério. Prevenção de danos e a extensão do princípio neminem laedere. In: NERY, Rosa Maria de Andrade; DONNINI, Rogério (Org.). Responsabilidade civil: estudos em homenagem ao Professor Rui Geraldo Camargo Viana. São Paulo: Revista dos Tribunais, 2009. p. 499).

159 PIZARRO realiza esta mesma crítica, apesar de ele se referir ao direito argentino, mas ela cabe também ao direito brasileiro (PIZARRO, Ramón Daniel. Daño moral. Prevención. Reparación. Punición. El daño moral en las diversas ramas del Derecho. Hammurabi, 2000. p. 372).

160 MORAES, Maria Celina Bodin de. Punitive damages em sistemas civilistas: problemas e perspectivas. Revista Trimestral de Direito Civil, Rio de Janeiro, v. 18, 2004. p. 46-49. 
do consumidor em juízo, a critério do juiz, de acordo com a gravidade e a proporção do dano, bem como a situação econômica do responsável.

Ademais, a Autora fala do Projeto de Lei n. 6.960/2002, do relator deputado Ricardo Fiúza, que tipificava a indenização punitiva na responsabilidade civil, mas não foi aprovado. Não havia critérios orientativos da atividade do juiz.

A questão referente à crítica do princípio da legalidade pode ser solucionada com a edição de uma lei que regule as hipóteses, os critérios, o método utilizado pelo juiz para arbitrar a punição do agente:

Esta é, na realidade, a solução que se apresenta mais condizente para com o instituto da pena privada - ou da indenização punitiva - nos países civilistas: normatizar as fattispecie consideradas, do ponto de vista do legislador democrático, como merecedoras de aplicação de pena pecuniária ou multa civil. A questão é, evidentemente, de ordem filosófica e sociológica e, sucessivamente, de política legislativa, hipóteses em relação às quais serão sempre insuficientes às soluções (necessariamente) casuísticas da jurisprudência. ${ }^{161}$

Como é uma indenização punitiva, os parâmetros e os meios de defesa do réu devem ser regulados por algum dispositivo ou alguma lei, portanto, a previsão legislativa é de extrema necessidade. ${ }^{162}$

Andrade defende que não há relação do princípio com as sanções punitivas na esfera privada. No que concerne à "forma" ou à "qualidade", não há diferença entre a sanção pecuniária e a sanção reparatória. Há uma diferenciação nos fundamentos e na função de cada uma. Ambas são pecuniárias e destinam sancionar um dano.

161 MORAES, Maria Celina Bodin de. Punitive damages em sistemas civilistas: problemas e perspectivas. Revista Trimestral de Direito Civil, Rio de Janeiro, v. 18, 2004. p. 55.

$162 \ldots$ Danos à pessoa humana: uma leitura civil-constitucional dos danos morais. Rio de Janeiro: Renovar, 2003. p. 260. Schreiber e Tepedino criticam a função punitiva e põem em discussão algumas adotadas pelos defensores da função punitiva, mas eles abrem uma hipótese para que uma norma possa dispor e regular a aplicação da função punitivo-preventiva (SCHREIBER, Anderson; TEPEDINO, Gustavo. As penas privadas no direito brasileiro. In: SARMENTO, Daniel; GALDINO, Flavio. Direitos fundamentais: estudos em homenagem Ricardo Lobo Torres. Renovar: Rio de Janeiro, 2006. p. 524). Pizarro aprova a possibilidade de o legislador abrir exceções à discussão e fixar hipóteses de punições em caso de danos morais, mas sua posição é de que os casos de danos morais não podem abranger duas funções na reparação, compensatória e punitiva, por estas agirem com princípios diferentes. Assim, a reparação teria função meramente compensatória e não punitiva na quase totalidade dos casos, exceto naqueles em que o legislador poderia fixar quantum majorado com intuito punitivo. (PIZARRO, Ramón Daniel. Daño moral. Prevención. Reparación. Punición. El daño moral en las diversas ramas del Derecho. Hammurabi, 2000. p. 92 e p. 400). 
$\mathrm{Na}$ indenização, há correspondência com a extensão do dano de modo que não é imprevisível o quantum indenizatório. A sanção pecuniária penal não se relacionaria a algo estimável, no entanto, há ditames legais que retirar o aspecto "surpresa" para o réu. Andrade atesta que o elemento surpresa característico da indenização punitiva, pelo fato de não haver uma previsão legal anterior, não constitui um óbice para sua aplicação. O fundamento é de que os lucros cessantes carregam uma subjetividade em torno de si e que a própria reparação por danos morais (seja compensatória ou punitiva) possuem o elemento surpresa. ${ }^{163}$

Andrade diz que é preciso abordar sobre a quantidade e a qualidade das penas para abordar a questão do princípio da legalidade. Sobre a qualidade das penas cabe à lei. Sobre a pena ser de prisão, etc., cabe à lei, enquanto que a quantidade cabe ao próprio juiz.

A qualidade especial da sanção pecuniária se mostra no fato de o legislador penal não ter referido a limites no quantum da multa para cada crime. O que se percebe é que a sanção pecuniária, pela sua essência, ajusta-se menos facilmente ao domínio do Direito Penal que a outros domínios.

O Código Penal não determinar o quantum para cada tipo de crime, mas, na Parte Geral estabeleceu limites que são "aplicáveis indistintamente a todos os tipos que prevejam a cominação de multa. Essa igualação abstrata da pena de multa permite, em tese, que um crime de menor gravidade receba multa superior a de um crime de maior gravidade". ${ }^{164}$

Complementando o raciocínio, o autor explica que "seria impensável a adoção de técnica semelhante para as penas privativas de liberdade. Ninguém ousaria defender, por exemplo, a possibilidade de a lei estabelecer, em um artigo geral, em consideração a gravidade do delito e a culpabilidade do agente". ${ }^{165}$

Outro argumento de Andrade é que, apesar das diferenças em relação à multa no Direito Penal, a indenização punitiva é importante para defender a dignidade humana da vítima. Pensando nas ofensas do princípio da dignidade humana ao lado do princípio da anterioridade das penas, observa-se que deve haver a prevalência da tutela da dignidade humana, segundo o Autor. ${ }^{166}$

163 ANDRADE, André Gustavo Corrêa. Dano moral e indenização punitiva. 2. ed. rev. e atual. Rio de Janeiro: Lumen Juris, 2009. p. 288.

164 Ibid., p. 291.

165 Ibid., loc. cit.

166 Ibid., p. 293. "Ressalte-se que não se está a admitir que a indenização punitiva colida com o princípio da anterioridade da lei penal. Reitera-se aqui o entendimento, já manifestado, de que o princípio da anterioridade não se dirige às sanções pecuniárias estabelecidas fora do âmbito penal" (Ibid., p. 294). 
Adotando outro raciocínio, Boris Starck sustenta o caráter substantivo diferente da sanção pecuniária e das outras sanções penais. Estas se caracterizam por compreender condutas mais graves, com repressão e caráter preventivo. As sanções penais são mais intensas e "desonrosas" do que as sanções penais, de modo que o princípio da legalidade aparece incidindo somente sobre o Direito Penal e não no Direito Civil. O autor defende que somente as sanções penais, por serem mais graves e por se relacionarem à liberdade e a integridade do agente, são abrangidas pelo princípio da legalidade. Assim o é, embora haja condenações civis duras e rígidas. ${ }^{167}$

Bassan critica este argumento de Andrade sustentando que a natureza da sanção não define a necessidade de respeitar ou não o princípio da legalidade. Além disso, a Autora diz que o Direito Penal também se rege por normas de Direito Civil, ${ }^{168}$ com o intuito de sustentar a aplicação do princípio da legalidade no Direito Civil.

Bassan sustenta que não há normas que permitem a indenização punitiva no Direito Civil ${ }^{169} \mathrm{e}$, também, não há regras que regulem e limitem o arbítrio do juiz no arbitramento dessas indenizações punitivas. Além disso, a autora explica que as normas e sanções do Direito Penal possui plena regulação nas normas penais de modo que a atividade punitiva do Estado possui freios em seu funcionamento. Com esse raciocínio, a prática de indenizações punitivas na responsabilidade civil não pode fugir à legalidade, portanto, deve-se ter uma norma permitindo-as. ${ }^{170}$

Andrade notou o aspecto prático que há no funcionamento das sanções penais e as civis. No caso da sanção pecuniária do Direito Penal, vê-se que a lei definiu a multa como a pena, porém, não determinou o quantum, que estaria nas mãos do juiz.

Em contrapartida, embora o autor pareça estar correto em sua análise, o aspecto punitivo da indenização deve vir associado a medidas protetivas do réu, ou seja, garantias devem existir para que haja uma segurança jurídica e para que haja devido processo legal na punição do agente. ${ }^{171}$

167 STARCK, Boris. Essai d'une théorie générale de la responsabilité civile considérée en sa double fonction de garantie et de peine privée, p. 383 apud ANDRADE, André Gustavo Corrêa. op. cit., p. 175.

168 "Quando se fixa um valor indenizatório, no intuito de punir o causador do dano, não é dado a este conhecer os limites dessa punição, configurando-se tal situação em flagrante desrespeito ao princípio em questão. A jurisprudência claramente mostras que, ao assumir uma postura punitiva, o juiz vale-se de amplos poderes na fixação da indenização, gerando distorções absurdas quanto à função compensatória da indenização por danos morais. Essa suposta "discricionariedade" ofende, frontalmente, a garantia posta pelo princípio da legalidade" (BASSAN, Maria Alcazas. As funções da indenização por danos morais e a prevenção de danos futuros. Dissertação (Mestrado) - Faculdade de Direito, Universidade de São Paulo, São Paulo. p. 72).

169 No mesmo sentido, SCHBEIRER, Anderson. Arbitramento do dano moral no Novo Código Civil. Revista Trimestral de Direito Civil, Rio de Janeiro, v. 12, out./dez. 2002. p. 13.

170 BASSAN, Maria Alcazas. As funções da indenização por danos morais e a prevenção de danos futuros. 2009. Dissertação (Mestrado) - Faculdade de Direito, Universidade de São Paulo, São Paulo. p. 73.

171 Ibid., p. 73-74. Levy explica o tratamento dado à questão da função punitiva na Europa continental. A jurisprudência francesa aplica a indenização punitiva de maneira tácita, por meio de fundamentação dos 
Dessa forma, reputamos importante a edição de um dispositivo expresso que regule as hipóteses e as condições de aplicação da função punitiva, ${ }^{172}$ devido ao seu caráter indispensável e à sua necessidade, seguindo as discussões, apesar de posicionamentos contrários, ${ }^{173}$ ainda que a responsabilidade civil seja mais flexível e com um funcionamento diferente da responsabilidade penal.

f) A indenização mede-se pela extensão do dano e não pela extensão da culpa ${ }^{174}$

Com o exercício da indenização punitiva na indenização por danos morais, o comportamento do agente deverá ser levado em conta para aferir a amplitude de sua culpabilidade. Suas condutas, os efeitos do dano moral, as circunstâncias do caso concreto e o patrimônio do ofensor deverão ser considerados para o arbitramento do quantum.

Bassan manifesta essa crítica afirmando que o art. 944, parágrafo único, CC só permite a utilização da culpa para reduzir o quantum da responsabilidade, o que inviabilizaria qualquer hipótese de utilização da culpa para majorar o montante (punição).

Adotando o posicionamento contrário, como vimos anteriormente, o art. 944, parágrafo único, CC contempla a possibilidade de a culpa ser utilizada para reduzir o quantum e, embora não manifestando expressamente, demonstra a viabilidade de a culpa ser importante para ser aplicada na majoração do montante, com intuito de punir o agente. Neste sentido, Benacchio possui o entendimento de que o art. 944, parágrafo único, CC apresenta o princípio que permite a aplicação da função punitiva, em adequação ao texto constitucional (art. 5 $5^{\circ} \mathrm{V}$ e X, CF).

juízes não muito precisa. $\mathrm{O}$ caráter sintético das decisões não permite saber o caminho percorrido pelo juiz para chegar no valor final de indenização. Se eles fundamentam com base na função punitiva, a decisão é cassada devido à prevalência do princípio da reparação integral. Na Itália, há a aplicação da indenização punitiva devido à influência da religião católica que era contra ao pagamento dado à dor. Mas, essa prática conflita com a tendência de não se aceitar a indenização punitiva no direito italiano. A conclusão do autor é que, na Europa, há uma resistência em se aplicar a função punitiva, salvo no caso da Inglaterra (LEVY, Daniel de Andrade. Responsabilidade civil: de um direito dos danos a um direito das condutas lesivas. São Paulo: Atlas, 2012. p. 79-88).

172 Neste sentido, SCHREIBER, Anderson; TEPEDINO, Gustavo. As penas privadas no direito brasileiro. In: SARMENTO, Daniel; GALDINO, Flavio. Direitos fundamentais: estudos em homenagem Ricardo Lobo Torres. Renovar: Rio de Janeiro, 2006. p. 520.

173 "Não há que se esperar a formulação de lei expressa para se punir uma ofensa à cláusula geral de dignidade que, por ser cláusula geral, deverá o juiz concorrer ativamente para a formulação da norma, em que considerará a noção de dignidade efetivamente vigente (não a dele, mas aquela objetivamente considerada) e estabelecerá as consequências jurídicas desta violação" (MELO, Diogo Leonardo Machado de. Ainda sobre a função punitiva na reparação por danos morais (e a destinação de parte da indenização para entidades de fins sociais - art. 883, parágrafo único, do Código Civil). Revista de Direito Privado, São Paulo, v. 7., n. 26, abr./jun. 2006. p. 135). Vaz sustenta que a falta de previsão legislativa não é óbice para o reconhecimento do instituto, porém, a aplicação dele requer, a nosso ver, a edição de norma regulamentando os critérios (VAZ, Caroline. Funções da responsabilidade civil: da reparação à punição e dissuasão: os punitive damages no Direito Comparado e Brasileiro. Porto Alegre: Livraria do Advogado, 2009. p. 82).

174 BASSAN, Maria Alcazas. op. cit., p. 70 e SCHREIBER, Anderson; TEPEDINO, Gustavo. op. cit., p. 522. 
Cunha sustenta que os arts. 944 e 945, CC denotam também importância e a consideração da culpa no arbitramento do montante da indenização. $\mathrm{O}$ autor fala que os dispositivos dizem respeito à redução da indenização com base na culpa, mas elas trazem "uma verdadeira cláusula geral de influência e de análise da culpa na fixação dos danos":"175

Sob essa ótica, se funcionam essas duas normas e a cláusula geral que delas deriva como mais um fundamento para a admissão do grau de culpa como critério para a fixação de dano no direito brasileiro, no caso danos morais e danos punitivos, também podem ser tidas, em conjunto, como mais uma justificativa normativa para a admissão desses últimos no Direito brasileiro. ${ }^{176}$

Da maneira que propomos, a função punitiva substancia-se num montante diferente daquele destinado à reparação dos danos. Este deve sim respeitar o art. 944, parágrafo único, CC, incidindo a extensão do dano como determinante para a reparação. $\mathrm{O}$ outro montante baseia-se no comportamento do agente, principalmente sua culpabilidade. A partir disso, o art. 944, parágrafo único, CC não incide, pois não se trata mais de reparação, mas a causa do quantum é outro, ou seja, trata-se de uma verdadeira punição.

Um ponto interessante é a aplicação da função punitiva em hipóteses de responsabilidade objetiva. A culpa não é requisito para a responsabilidade civil, mas ela pode ser comprovada e utilizada para fins de função punitiva também, segundo Serpa. ${ }^{177}$

Essa discussão pode parecer meramente acadêmica, pois seria sobre um dispositivo e interpretações que buscam fundamentar a punição, mas ela é importante porque lida com um motivo relevante que é um permissivo legal que autorize a função punitiva. Neste sentido, pensar que o art. 944, parágrafo único, CC consagre a função punitiva retira completamente a crítica de violação ao princípio da legalidade.

g) Possível bis in idem

O bis in idem ocorreria se houvesse a punição na responsabilidade civil e, também, na seara da responsabilidade penal. ${ }^{178}$

Apesar de outras posições, como aquela em que as duas punições vão incidir sobre o agente sem nenhuma variação ou influência de uma na outra; ${ }^{179}$ ou, fundamentando-

\footnotetext{
175 CUNHA, Wladimir Alcibíades Marinho Falcão. Danos extrapatrimoniais e função punitiva. 2012. Tese (Doutorado) - Faculdade de Direito, Universidade de São Paulo, São Paulo. p. 157 e ss.

176 Ibid., p. 158.

177 SERPA, Pedro Ricardo e. Indenização punitiva. 2011. Dissertação (Mestrado) - Faculdade de Direito, Universidade de São Paulo, São Paulo. p. 205.

178 Ibid., p. 209.

179 GUIMARÃES, Patrícia Carla Monteiro. Os danos punitivos e a função punitiva da responsabilidade civil. Direito e Justiça: Revista da Faculdade de Direito da Universidade Católica Portuguesa, v. 15, n. 1, p. 159206, 2001. p. 175.
} 
se no art. 935, CC, a posição de que pode haver duas punições de ramos diferentes desde que haja a mesma característica (por exemplo, duas punições pecuniárias); seguimos a ideia de que se houver duas punições por um mesmo fato, no caso de um dano que receba punição na responsabilidade civil e penal, uma influencia a outra, de modo que o quantum receba uma ponderação devido a outra punição. Esta posição é adotada por $\operatorname{Serpa}^{180} \mathrm{e}$ Andrade. ${ }^{181}$

Entendemos que é plenamente possível a ponderação de ambas as punições de modo que elas possam existir conjuntamente, embora em searas diferentes.

\section{Conclusão}

No século XXI, a função preventiva ocupa o lugar principal da responsabilidade civil, sendo resultado da sociedade de risco que exige uma tomada de cautela nas atividades desenvolvidas pelos indivíduos. Neste sentido, a punição é colocada como instrumento de prevenção, de sorte que pensamos ser preferível chamar de função punitivo-preventiva porque há um realce da ideia de prevenir e não de meramente punir.

A aplicação da função punitivo-preventiva deve evitar o enriquecimento sem causa da parte lesada e estar em conformidade com outros princípios gerais do direito e do próprio direito civil. Neste sentido, o princípio da legalidade deve ser observado, é necessária uma previsão legal introduzindo esta finalidade punitivo-preventiva.

Por fim, cabe ressaltar que a punição na responsabilidade civil deve ser aplicada como medida marcada pela excepcionalidade, não podendo ser introduzida em todos os tipos de danos, mas, sim, nas hipóteses nas quais o agente não receber um estímulo a prevenir os danos. O juiz deverá trazer sua fundamentação e separar o quantum reparatório e punitivo porque apenas dessa forma terá a publicidade do efeito punitivo da decisão do juiz, caso contrário, o agente não terá ciência da repulsa do Direito em relação à sua conduta.

São Paulo, 28 de maio de 2014.

\section{Referências}

AMARAL, Claudio do Prado. Despenalização pela reparação de danos: a terceira via. Leme: J. H. Mizuno, 2005.

180 SERPA, Pedro Ricardo e. Indenização punitiva. 2011. Dissertação (Mestrado) - Faculdade de Direito, Universidade de São Paulo, São Paulo. p. 209 e ss.

181 ANDRADE, André Gustavo Corrêa. Dano moral e indenização punitiva. 2. ed. rev. atual. Rio de Janeiro: Lumen Juris, 2009. p. 295. 
ANDRADE, André Gustavo Corrêa. Dano moral e indenização punitiva. 2. ed. rev. e atual. Rio de Janeiro: Lumen Juris, 2009.

AZEVEDO, Antonio Junqueira de. Por uma nova categoria de dano: o dano social. In: Novos estudos e pareceres de direito privado. São Paulo: Saraiva, 2009.

BASSAN, Maria Alcazas. As funções da indenização por danos morais e a prevenção de danos futuros. 2009. Dissertação (Mestrado) - Faculdade de Direito da Universidade de São Paulo, São Paulo.

BAUMAN, Zygmunt. Medo líquido. Trad: Carlos Alberto Medeiros. Rio de Janeiro: Zahar, 2008.

BENACCHIO, Marcelo. A função punitiva na responsabilidade civil no Código Civil. In: LOTUFO, Renan; NANNI, Giovanni Ettore; MARTINS, Fernando Rodrigues (Org.). Temas relevantes do direito civil contemporâneo: reflexões sobre os 10 anos do Código Civil. São Paulo: Atlas, 2012.

CARMIGNANI, Maria Cristina. A evolução histórica do dano moral. Revista do Advogado, n. 49, dez. 1996.

CAVALIERI FILHO, Sérgio. Programa de responsabilidade civil. São Paulo: Atlas, 2012.

COSTA, Judith Martins; PARGENDLER, Mariana Souza. Usos e abusos da função punitiva. Revista CEJ/Conselho da Justiça Federal, Brasília: CEJ, v. 9, n. 28, jan./mar. 2005.

CUNHA, Wladimir Alcibíades Marinho Falcão. Danos extrapatrimoniais e função punitiva. 2012. Tese (Doutorado) - Faculdade de Direito, Universidade de São Paulo, São Paulo.

DIAS, José de Aguiar. Da responsabilidade civil. Rio de Janeiro: Forense, 1944. v. 1.

DONNINI, Rogério. Prevenção de danos e a extensão do princípio neminem laedere. In: NERY, Rosa Maria de Andrade; DONNINI, Rogério (Org.). Responsabilidade civil: estudos em homenagem ao Professor Rui Geraldo Camargo Viana. São Paulo: Revista dos Tribunais, 2009.

FERREIRA, Keila Pacheco. Prevenção e responsabilidade civil: revisitando os aspectos teleológicos na primeira década do CC. In: LOTUFO, Renan; NANNI, Giovanni Ettore; MARTINS, Fernando Rodrigues (Org.). Temas relevantes do direito civil contemporâneo: reflexões sobre os 10 anos do Código Civil. São Paulo: Atlas, 2012.

GUIMARÃES, Patrícia Carla Monteiro. Os danos punitivos e a função punitiva da responsabilidade civil. Direito e Justiça: Revista da Faculdade de Direito da Universidade Católica Portuguesa, v. 15, n. 1, p. 159-206, 2001.

HARTMANN, Ivar Alberto Martins. O princípio da precaução e sua aplicação no direito do consumidor: dever de informação. Revista de Direito do Consumidor, a. 18, n. 70, p. 172-235, abr./ jun., 2009.

LEVY, Daniel de Andrade. Responsabilidade civil: de um direito dos danos a um direito das condutas lesivas. São Paulo: Atlas, 2012. 
LEWICKI, Bruno. Princípio da precaução: impressões sobre o segundo momento. In: MORAES, Maria Celina Bodin de (Coord.). Princípios do direito civil contemporâneo. São Paulo: Renovar, 2006.

LOPEZ, Teresa Ancona. Princípio da precaução e evolução da responsabilidade civil. São Paulo: Quartier Latin, 2010.

MARINANGELO, Rafael. A evolução da indenização por dano moral e a aplicação da indenização punitiva, In: LOTUFO, Renan; NANNI, Giovanni Ettore; MARTINS, Fernando Rodrigues (Org.). Temas relevantes do direito civil contemporâneo: reflexões sobre os 10 anos do Código Civil. São Paulo: Atlas, 2012.

MELO, Diogo Leonardo Machado de. Ainda sobre a função punitiva na reparação por danos morais (e a destinação de parte da indenização para entidades de fins sociais - art. 883, parágrafo único, do Código Civil). Revista de Direito Privado, São Paulo, v. 7, n. 26. p. 105-145, abr./jun. 2006.

MORAES, Maria Celina Bodin de. Danos à pessoa humana: uma leitura civil-constitucional dos danos morais. Rio de Janeiro: Renovar, 2003.

. Punitive damages em sistemas civilistas: problemas e perspectivas. Revista Trimestral de Direito Civil, Rio de Janeiro, v. 18, 2004.

MORSELLO, Marco Fábio. A responsabilidade civil e a socialização dos riscos. O sistema neozelandês e a experiência escandinava. Revista da Escola da Magistratura, a. 7, n. 2, jul./dez. 2006.

NORONHA, Fernando. Direito das obrigações. 3. ed. São Paulo: Saraiva, 2010.

PIZARRO, Ramón Daniel. Daño moral. Prevención. Reparación. Punición. El daño moral en las diversas ramas del Derecho. Caba: Hammurabi, 2000.

SANTOS BRIZ, Jaime. La responsabilidad civil: derecho substantivo e derecho procesal. 3. ed. Madrid: Editora Montecorvo, 1981, p. 41 e ss.

SCHBEIRER, Anderson. Arbitramento do dano moral no Novo Código Civil. Revista Trimestral de Direito Civil, Rio de Janeiro, v. 12, out./dez. 2002.

. Novas tendências da responsabilidade civil brasileira. Revista Trimestral de Direito Civil, Rio de Janeiro, v. 22, p. 45-69, abr./jun., 2005.

. Novos paradigmas da responsabilidade civil: da erosão dos filtros da reparação à diluição dos danos. 4. ed. São Paulo: Atlas, 2012.

; TEPEDINO, Gustavo. As penas privadas no direito brasileiro. In: SARMENTO, Daniel; GALDINO, Flavio. Direitos fundamentais: estudos em homenagem Ricardo Lobo Torres. Renovar: Rio de Janeiro, 2006. 
SERPA, Pedro Ricardo e. Indenização punitiva. 2011. Dissertação (Mestrado) - Faculdade de Direito, Universidade de São Paulo, São Paulo. p. 139 e ss.

ULIAN, Eduardo. Responsabilidade civil punitiva. 2003. Tese (Doutorado) - Faculdade de Direito, Universidade de São Paulo, São Paulo.

VAZ, Caroline. Funções da responsabilidade civil: da reparação à punição e dissuasão: os punitive damages no Direito Comparado e Brasileiro. Porto Alegre: Livraria do Advogado, 2009.

ZANNONI, Eduardo. El daño en la responsabilidad civil. 2. ed. Buenos Aires: Astrea, 1993. 
